\title{
How to measure bank credit risk disclosure? Testing a new methodological approach based on the content analysis framework
}

\author{
Enzo Scannella ${ }^{1} \cdot$ Salvatore Polizzi ${ }^{1}$
}

Published online: 28 July 2020

(c) The Author(s) 2020

\begin{abstract}
Risk disclosure is a crucial factor in enhancing the efficiency of financial markets and promoting financial stability. This paper proposes a methodological tool to analyze credit risk disclosure in bank financial reports, based on the content analysis framework. The authors also uses this methodology to carry out an empirical study on a small sample of large Italian banks. The paper provides preliminary empirical evidence that banks differ in their credit risk disclosure, even though they are subject to homogeneous regulatory and accounting requirements. Furthermore, by carrying out a correlation-based network analysis, the paper provides preliminary evidence on the existence of a relationship between credit risk disclosure, bank size, and business model. The existing literature has not provided any methodological tool to analyze qualitative and quantitative profiles of bank credit risk disclosure. In order to fill this gap, we propose an original research methodology to investigate bank credit risk reporting. While previous contributions have examined related aspects adopting automated content analysis techniques, this paper proposes an original and non-automated content analysis approach. Our research has several regulatory and strategic implications and lays the foundation for further research in banking, finance, and accounting.
\end{abstract}

Keywords Credit risk $\cdot$ Risk reporting $\cdot$ Risk disclosure $\cdot$ Risk management $\cdot$ Banking

JEL Classification $\mathrm{G} 2 \cdot \mathrm{G} 18 \cdot \mathrm{G} 21 \cdot \mathrm{G} 24 \cdot \mathrm{G} 28 \cdot \mathrm{G} 32$

\section{Introduction}

Risk disclosure in banking contributes to reducing asymmetric information among stakeholders $[1,2]$ and solving agency problems [3-6] that arise because of the different interests between a principal and an agent in the banking industry. In this perspective, risk disclosure is an incentive tool $[7,8]$ to find a balance between divergent interests, and

Although the paper has been written jointly by the two Authors it is possible to identify the contribution of each one as follows. Abstract and second, fourth and sixth sections have been written by Enzo Scannella. Sections two and three have been written jointly by Enzo Scannella and Salvatore Polizzi. Fifth section has been written by Salvatore Polizzi. The data were analyzed jointly by the two Authors. All the figures and tables were prepared jointly by the two Authors.

Enzo Scannella

enzo.scannella@unipa.it

1 Department of Economics, Business, and Statistics, University of Palermo, Building n. 13, Viale delle Scienze, 90128 Palermo, Italy offers an opportunity to improve the screening, selection, and monitoring functions [9] carried out by depositors, investors, and other stakeholders. In addition, risk disclosure performs a signalling function for the market $[2,10]$. Asymmetric information makes it difficult for stakeholders to monitor and evaluate the level of risk assumed by bank managers. An adequate credit risk disclosure is important for stakeholders to assess the potential risk of any investment opportunity, and to evaluate the soundness and riskiness of bank strategic decisions in the lending business. Furthermore, credit risk reporting is fundamental to promote market discipline and to inspire trust in bank stakeholders.

Risk disclosure is tightly related to the cost of capital of the bank [11-14], and it is important for the proper functioning of market and nonmarket mechanisms that put a limit on bank debt level, enhancing the stability of the financial system [15-20].

Risk disclosure is a crucial factor to improve the efficiency of financial markets [21] and financial stability. The correct functioning of financial markets requires a uniform distribution of information, and bank risk disclosure 
is crucial to achieve this goal. Moreover, high-quality risk disclosure can be considered a collective public good [22, 23], which produces positive externalities [24].

Our research aims to provide a methodological tool to evaluate the qualitative and quantitative profiles of bank risk disclosure, with reference to credit risk on loan portfolio. We propose a hybrid scoring model based on the content analysis framework [28] to assess the ability of banks to provide an adequate credit risk disclosure. We also use this methodology to analyze the disclosure of a sample of Italian banks, taking into account the International Accounting Standards and International Financial Reporting Standards (IAS/IFRS), the Pillar 3 disclosure requirements of the New Basel Capital Accord [25-27], and the national regulatory framework for banks' annual financial statements.

Content analysis is a methodology that has been used by numerous researchers to examine and evaluate risk reporting, as a "research technique for making replicable and valid inferences from texts to the contexts of their use" [28], and as "a research technique for the objective, systematic and quantitative description of the manifest content of communication" [29]. Content analysis has been applied to a variety of scopes [30, 31]. Noticeably, no study has provided a methodological tool researcher and analysts can use to measure and evaluate credit risk disclosure in the banking industry. In order to fill this gap, this paper proposes an original and non-automated approach.

To preview our main results, we provide preliminary evidence that (1) banks differ in their credit risk disclosure, even though they are subject to similar regulatory requirements; (2) there are various areas of improvements in bank credit risk disclosure, mainly related to the poor forwardlooking disclosure, disclosure fragmentation and the marginal role of the management commentary; (3) by carrying out a correlation-based network analysis, we hypothesize the existence of a relationship among credit risk disclosure, bank size and business model. In this regard, we remark that our analysis is exploratory in nature, given that the extant literature has not provided any methodological tool to analyze credit risk disclosure in the banking industry. Hence, our results are preliminary pieces of evidence about credit risk disclosure, which need to be confirmed by future research.

Our analysis paves the way for more comprehensive analyses that could analyze larger samples, longer time horizons, test general theories and provide generalizable results.

The structure of this paper is as follows. Second section provides a literature review on risk disclosure. Third section describes our hybrid scoring model. Fourth section analyzes the main preliminary results of the empirical research and discusses their potential theoretical and policy implications. Fifth section provides a correlation-based network analysis of bank credit risk disclosure indexes. Sixth section concludes.

\section{Literature review on risk disclosure}

Risk disclosure in banking has received increasing attention among finance and accounting scholars over the last decades. Voluntary and mandatory risk disclosure have been examined from several different perspectives. In this section, we review the most important studies on risk disclosure.

Most research on risk disclosure focuses on non-financial firms and examines the relationship between firm size and risk disclosure quality [32-39]. A specific stream of literature focuses on the risk disclosure of financial instruments in the annual reports of financial and non-financial firms [40-44]. It is also important to mention the work of Ryan [45] on the implications of academic research for financial reporting policy.

Since the 1980s, scholars have been tried to create disclosure indexes to study and evaluate risk disclosure in annual reports [46, 47], and some of them tried to assess whether they are associated with some independent variables [48]. Firm size, financial leverage, and the listing in stock exchange markets have been identified as the main factors which influence risk disclosure [49]. Since then, an expanding stream of literature has been produced. However, dealing with the evolution of the whole scientific literature regarding risk disclosure from early 1980 to 2019 is a demanding task, which goes beyond the aims of this paper. For a complete review on risk reporting see Marston and Shrives [50], Core [51], and Elshandidy, Shrives, Bamber and Abraham [52], while for a literature review on this topic for the banking sector, see Beattie and Liao [53].

Beretta and Bozzolan [54, 55] and Bozzolan et al. [56] provide an important contribution in the field. More specifically, Beretta and Bozzolan [55] criticize the general assumption that disclosure quantity can be considered a proxy for the quality of the information provided in financial statements. The authors propose an index of disclosure quality to investigate whether financial statements can really support potential investors in taking rational and conscious economic decisions. Bozzolan et al. [56] highlight the importance of forward-looking disclosure. In particular, the authors state that two qualitative characteristics are fundamental for financial analysts and potential investors, namely accuracy and verifiability. Thus, the literature which investigates into risk disclosure quality (especially when focusing on the two aforementioned qualitative characteristics) and tackles the issue of forward-looking information might be extremely valuable.

As for the banking studies, the literature on financial firm risk reporting is still rather scarce. Linsley and Shrives [57] and Linsley et al. [58] provide the first studies 
on risk disclosure in banks' annual reports using a content analysis approach. The authors show that most banks tend to disclose backward-looking rather than forward-looking information, even if the latter is probably the most useful for investors. Hence, understanding to what extent narrative risk disclosure is useful for financial statement users is a challenging and crucial task, especially in the banking industry. Also, according to these scholars another critical aspect which requires further investigation is the use of backward-looking and forward-looking disclosure.

Other important studies on bank risk reporting are performed by Barth and Landsman [59], Fortuna [60], Gaetano [61], Helbok and Wagner [62], Malinconico [63], Maffei [64], Scannella [65], Scannella and Polizzi [66], Woods et al. [43, 44]. On closer inspection, Malinconico [63] provides an analysis of the impact of bank risk disclosure on market discipline, while Scannella [65], Scannella and Polizzi [66], and Woods et al. [43, 44] employ content analysis to evaluate market risk reporting. They find that, notwithstanding the global convergence of accounting standards, the progress toward harmonization at international level is still unsatisfactory. These contributions show that content analysis is a useful and powerful methodology to investigate risk disclosure. However, these papers focus specifically on market risk reporting. Hence, it is straightforward to understand that an extension of this kind of analysis on other types of risk in banking (mainly credit and operational risk) is fundamental to increase our knowledge in this field [67, 68].

As for the contributions on bank credit risk disclosure, although credit risk is the central and the most traditional kind of risk for commercial banks, the literature is quite scarce. Some contributions study credit risk reporting from a theoretical point of view, analyzing bank financial statements [69-71] emphasizing the central role of credit risk management in the banking industry. With reference to the empirical studies on this specific field, to the best of our knowledge the only paper which addresses this specific problem is Frolov [72], which is undoubtedly an interesting study, but quite old. Hence, since risk reporting in banking is an ongoing and evolutionary process $[66,70]$, it is straightforward to understand that it is crucial to provide further contributions to this specific field of research.

Noticeably, from the analysis of the literature, it emerges that no study has provided a methodological tool researcher and analysts can use to measure and evaluate credit risk disclosure in the banking industry. The only empirical study on the same topic is that of Frolov [72], who relies on a survey performed by the Japan Investor Relations Association in 2004, without developing a methodological technique to examine credit risk disclosure. While other metrics have been proposed for market risk $[43,66]$ and operational risk [89], there is surprisingly no methodological tool available to analyze credit risk disclosure. This paper aims to fill this
Table 1 Sample of the empirical research

\begin{tabular}{ll}
\hline Bank & $\begin{array}{l}\text { Total assets (2017) } \\
\text { (in million euro) }\end{array}$ \\
\hline Unicredit & 836.790 \\
Intesa Sanpaolo & 796.861 \\
Monte dei Paschi di Siena $^{a}$ & 139.154 \\
Banco Popolare $^{\mathrm{a}}$ & 117.411 (year 2016) \\
& 161.207 (BPM: year \\
& 2017 ) \\
UBI Banca $_{\text {Banca Nazionale del Lavoro }}$ & 127.376 \\
Mediobanca $^{\mathrm{b}}$ & 78.934 \\
BPER Banca $^{\text {Banca Popolare di Milano }}{ }^{\mathrm{a}}$ & 70.446 \\
Banca Popolare di Vicenza $^{\mathrm{c}}$ & 71.339 \\
\hline
\end{tabular}

${ }^{a}$ On 1 January 2017, the two former banks Banco Popolare and Banca Popolare di Milano merged to become Banco BPM

${ }^{\mathrm{b}}$ Financial statement of Mediobanca as at 30 June 2017

${ }^{\mathrm{c}}$ On June 2017, Banca Popolare di Vicenza has been wound up under insolvency procedure (compulsory liquidation)

gap in the literature, by providing a metric to analyze bank risk disclosure focusing on credit risk.

The analysis of the literature clearly shows that several efforts are still necessary to study risk disclosure in banking. In particular, since credit risk is the most traditional one in commercial banking [73-77] and among the most delicate to manage for any financial firm, further research on credit risk disclosure could turn out to be fundamental. A proper investigation on this important topic has to assess the balance between backward-looking and forward-looking disclosure, and should analyze qualitative and quantitative information. In this regard, accuracy, truthfulness, and verifiability are, inter alia, key characteristics. Lastly, understanding whether the risk disclosure provided by different banks follows a similar trend over time is another key aspect, at least at national level, where regulation is homogeneous.

In sum, empirical research on bank risk disclosure practices, and specifically on credit risk, still requires further development and attention from banking, finance and accounting scholars.

\section{Credit risk disclosure in banking: a new methodological approach $\&$ research design}

This section of the paper describes the sample, the time horizon, and the methodology we propose to evaluate credit risk disclosure in banking.

The sample of this research consists of the 10 largest Italian banks for book value of total assets (Table 1), most of them are listed in the Italian stock market. These 
Table 2 Total number of pages of disclosure reports per year and bank

\begin{tabular}{llllllll}
\hline Total number of pages per year & 2012 & 2013 & 2014 & 2015 & 2016 & 2017 & Total \\
\hline Unicredit & 691 & 690 & 829 & 881 & 843 & 831 & 4765 \\
Intesa Sanpaolo & 602 & 633 & 661 & 640 & 659 & 704 & 3899 \\
Monte dei Paschi di Siena & 603 & 631 & 672 & 659 & 662 & 718 & 3945 \\
Banco Popolare & 516 & 542 & 563 & 562 & 583 & 687 & 3453 \\
UBI Banca & 475 & 490 & 539 & 468 & 469 & 499 & 2940 \\
Banca Nazionale del Lavoro & 350 & 372 & 388 & 299 & 293 & 299 & 2001 \\
Mediobanca & 296 & 287 & 286 & 337 & 349 & 369 & 1924 \\
BPER Banca & 513 & 534 & 559 & 612 & 655 & 656 & 3529 \\
Banca Popolare di Milano & 489 & 502 & 522 & 530 & 532 & 0 & 2575 \\
Banca Popolare di Vicenza & 509 & 522 & 594 & 544 & 579 & 0 & 2748 \\
Total & & & & & & & 31,779 \\
\hline
\end{tabular}

financial institutions represent approximately $60 \%$ of the Italian banking industry in terms of total assets (year 2017). This country-specific sample enhances the comparability across banks, as the financial institutions of the sample are subject to homogenous regulatory and accounting requirements. In addition, most of these banks are characterized by a predominant commercial banking business model, which remarks the strategic importance of credit risk. The choice to carry out a single-country sample analysis lies on our willingness to study bank credit risk disclosure, avoiding any concern related to the possible effects of different types of regulatory requirements on bank risk reporting practices. It would be difficult to control for the regulatory effects in a cross-country sample. The choice of selecting such a small sample to carry out our analysis is related to the fact that we want to stress the importance of proposing new insightful approaches to investigate into risk disclosure, rather than testing a general disclosure theory. Our main objectives do not involve the generalizability of our results, as our analysis is exploratory in nature, given that the existing literature has not provide any methodological tool to analyze bank credit risk disclosure by focusing on credit risk. Hence, this study provides just preliminary evidences about credit risk disclosure in banking, which need to be confirmed by future more comprehensive analyses that could draw upon the insights we provide. Nonetheless, our contribution extends our understanding on the way banks provide information about their credit risk exposure and management. Furthermore, the research methodology employed in this study is able to gather a considerable amount of information, even from a quite small sample, as it combines the characteristics of both a qualitative and quantitative approach.

The time horizon of this research runs from 2012 to 2017. We chose this time horizon to analyze the recently improved disclosure standards of the Pillar 3 report and some preliminary effects of the introduction of the new IFRS 9 in the banking industry. We analyze also bank comparability over time (for the same bank over different years) and across space (between different banks in the same year). Thus, our analysis takes into account both cross-sectional and time series data. This approach captures a much higher degree of information than a purely historical or cross-sectional approach.

Our data collection consists in the meticulous analysis and evaluation of the three aforementioned important risk disclosure reports: the Notes, the Management Commentary of the Annual Report and the Basel Capital Accord's Pillar 3 report, ${ }^{1}$ downloaded from banks' official websites. More specifically, concerning the Notes, the main focus is on Parts A (accounting policy), B (information on balance sheet), $\mathrm{C}$ (information on income statement), and $\mathrm{E}$ (information on banking risks). Nevertheless, the other parts of the document have been also taken into account, whenever they disclose useful information about credit risk. In total, we read and analyzed 31,780 pages of disclosure reports from 2012 to 2017 (Table 2).

We reviewed credit risk disclosure in annual reports and Pillar 3 reports of ten banks from 2012 to 2017 and, thereafter, constructed our disclosure quality index. In order to attenuate the subjectivity that affects this kind of analysis, we split the scoring model into two parts. The first part is based on an objective evaluation, while the second one is based on a judgment analysis. The final result is a hybrid scoring methodology, which evaluates qualitative and quantitative information using a semi-objective evaluation

\footnotetext{
${ }^{1}$ In this regard, it is important to notice that Banca Nazionale del Lavoro is under control of the French BNP Paribas. Consequently, its Pillar III report is a very short document. More comprehensive Pillar disclosure III reports are provided by BNP Paribas. In order to enhance the reliability of our analysis and take into consideration the most relevant pieces of information, we have examined also BNP Paribas' Pillar III report, with reference to the parts related to Banca Nazionale del Lavoro. Regrettably, it was not always feasible to isolate these disclosures. Furthermore, the Pillar III report provided by BNP Paribas does not disclose any relevant piece of information related to our metric.
} 
Table 3 First part of the scoring model: the analytical grid of credit risk disclosure indicators (score 0,1 )

Section 1-Definitions

Credit risk definition

Expected loan loss definition

Unexpected loan loss definition

Credit risk components definition (PD, LGD, EAD)

Credit risk weighted assets definition

Back-testing definition

Non-performing loans definition

Section 2-Calculations and limitations

Amount of expected loan loss

Amount of unexpected loan loss

Amount of credit risk weighted assets

Limitations of expected loan loss calculation

Limitations of unexpected loan loss calculation

Limitations of internal credit rating system

Limitations of loan loss provisioning methodologies

Potential credit risk exposures (on-balance sheet)

Potential credit risk exposures (off-balance sheet)

Section 3-Explanations

Explanation of expected loan loss models used

Explanation of unexpected loan loss models used

Explanation of provisioning for loan losses

Explanation of credit risk weighted assets calculation

Explanation of back-testing models used

Qualitative disclosure on non-performing loans portfolio

Explanation of credit risk mitigation/transfer instruments

Section 4-Other key disclosure parameters

Presence of graphs about expected and unexpected loan loss

Stress testing explanations

Stress testing results ${ }^{\mathrm{a}}$

Credit risk aggregation reported ${ }^{\mathrm{b}}$

Risk-adjusted performance indicators

Credit risk exposure limits and tolerance

Scenario analysis

${ }^{a}$ It is mandatory for credit internal stress test models only

'This indicator will return a score ' 1 ' if at least three of the following credit risk levels of aggregation will be reported: aggregation for type of loan; aggregation at portfolio level; aggregation at country level; aggregation for type of credit borrower; aggregation for the companies of the bank group

approach, supporting the adequateness of our scoring model. We use an analytical grid developed by focusing on thirty meaningful credit risk disclosure indicators (Table 3), based on a binary evaluation scheme. As shown in Table 4, these parameters are grouped into the following sub-categories: definitions, calculations and limitations, explanations, other key disclosure parameters. For each indicator, we assigned either ' 1 ' or ' 0 ' score. The score ' 1 ' means that
Table 4 Second part of the scoring model: the analytical grid of credit risk disclosure indicators (score 0-5)

Section A-Key aspects of credit risk management in banking

Explanation of credit risk management strategies

Explanation of credit risk management goals, procedures, processes, and policies

Explanation of credit risk measurements

Explanation of credit risk control systems

Section B-Credit risk management decision disclosure Information on credit risk assumption and retention

Information on credit risk prevention and protection

Information on credit risk transfer

Information on credit risk elimination and avoidance

Section C-Credit risk components

Insolvency risk

Migration risk

Recovery risk

Section D-Information on credit risk exposures

Current credit risk exposures (on-balance sheet)

Potential credit risk exposures (on-balance sheet)

Current credit risk exposures (off-balance sheet)

Potential credit risk exposures (off-balance sheet)

Accuracy of potential credit risk exposures assessment

Section E-Loan losses and measurement models

Credit risk: expected loss

Credit risk: unexpected loss

Measurement models for expected loss

Measurement models for unexpected loss

Model risk

Section F-Credit risk mitigation/transfer instruments

Information on collateral

Information on personal guarantees

Information on insurance contracts

Information on credit derivatives

Information on loan securitization

Section G-Other key elements of bank credit risk

Provisioning for loan losses

Analysis of non-performing loans

Information on specialized lending

Credit risk: balance sheet ratios

Section H-Bank loan portfolio disclosure

Loan portfolio composition

Loan portfolio correlation

Loan portfolio concentration

Credit risk aggregation and methodologies

Section I-Credit rating disclosure issues

Information on internal/external credit rating

Rating assignment

Rating quantification

Rating validation 
Table 4 (continued)

Information on accuracy of internal/external credit rating models
Implications of internal/external credit rating for bank manage-
ment
Section L_-Bank credit risk capital requirements disclosure
Credit risk-weighted assets (on- and off-balance sheet)
Measurement models for credit risk capital requirements
Capital adequacy for credit risk (regulatory perspective)
Economic capital for credit risk (internal and managerial perspec-
tive)
Section M-General credit risk disclosure issues
Backward-looking information on bank credit risk
Forward-looking information on bank credit risk
Provision of an integrated perspective on bank credit risk

the bank provides the information, whereas the score ' 0 ' means that the information is not reported. Analyzing carefully national and international regulatory requirements on bank financial reporting, we checked that all the information contained in this first part of the metric is not mandatory.

The second part of the scoring model is based on a judgment approach. We used another analytical grid, based on 47 key disclosure parameters that have an impact on the quality of bank credit risk reporting (Table 4). As shown in Table 4, these parameters are grouped into the following sub-categories: key aspects of credit risk management in banking, credit risk management decision disclosure, credit risk components, information on credit risk exposures, loan losses and measurement models, credit risk mitigation/transfer instruments, other key elements of bank credit risk, bank loan portfolio disclosure, credit rating disclosure issues, bank credit risk capital requirements disclosure, general credit risk disclosure issues. We assigned a score from ' 0 ' to ' 5 ', adopting the following scheme:

- Severe lack of information disclosure: score 0;

- Very poor information disclosure: score 1;

- Unsatisfactory information disclosure: score 2;

- Uatisfactory information disclosure: score 3;

- Good information disclosure: score 4;

- Excellent information disclosure: score 5.

We carried out our evaluation according to the following qualitative features: understandability, relevance, comparability, reliability. These qualitative characteristics are outlined in the Conceptual Framework for IAS/IFRS by the International Accounting Standard Boards [78]. These qualitative features of banks' financial statements are extremely important for credit risk reporting purposes. We argue that an appropriate balance among these qualitative characteristics of the information is crucial to provide a faithful and useful credit risk disclosure.
In order to increase the reliability of the evaluation of the second part of the analytical grid, and to improve the capability of our research to analyze the comparability across space and over time, we adopted the following approach [88]. Firstly, we analyzed Unicredit 2012 credit risk disclosure, which is the general benchmark of our evaluation process. Notice that it is the largest banks of our sample in terms of total assets, and according to the previous literature [43, 66], the larger the bank, the better its risk disclosure. Afterward, we analyzed the credit risk disclosure of Unicredit 2013, taking into account the disclosure of the previous year as a reference for the assignment of each score of each sub-section. With regard to the other years analyzed (from 2014 to 2017), our point of reference has been the disclosure of the previous year of the same bank, as the comparability over time is generally considered to be more substantial than the comparability over space [65]. As for the other banks of the sample, when carrying out the analysis of the disclosure of the year 2012, our benchmark has been Unicredit 2012, whereas for the years from 2013 to 2017, the reference point has been the disclosure of the previous year of the same bank. Overall, this approach makes the analysis much more reliable and also less subjective, and it enhances the comparability across space and over time of the scores of the banks analyzed.

In order to provide an in-depth explanation of the methodology, we now describe the aforementioned qualitative characteristics. The understandability refers to the fact that the information should be presented as clearly as possible, to make it easy to understand, with an appropriate balance between qualitative and quantitative information. Overall, classifying, characterizing, and presenting information clearly and concisely makes it understandable. It is tightly related to the capability of the reader to understand the correct meaning of the text. However, financial reports are prepared for users who have a deep knowledge of business and economic activities. Readability refers to the ease of understanding of a text and it has been considered as an indicator of comprehensibility.

The information is relevant when it is capable of influencing stakeholder decisions, and supports stakeholders in assessing the expected risks and returns of their investments. In this perspective, the information must be detailed enough to allow the reader to understand the nature of bank credit risk exposure. However, it is not always the case that the more information a bank discloses, the better off the user of the financial statement, as some information might confuse the reader.

The comparability is a crucial condition to provide meaningful information to stakeholders. It implies that the information can be compared with a similar information provided by other banks, and with similar information of the same bank in another time period. The comparability of bank disclosure, both across banks and over time, has recently been 
enhanced by the process of harmonization of the accounting languages started with IAS/IFRS.

The information is reliable when it reflects the economic substance of events and transactions, and not merely their legal form. It implies that the information must be verifiable, neutral, prudent, and faithfully representative of real economic phenomena.

An important consideration of the content analysis based on a hybrid scoring model is that both qualitative and quantitative data are examined. The first part of our metric deals with just a small subset of quantitative and qualitative data (such as the definition of credit risk, the definition of credit risk components, the explanation of credit risk weighted assets calculation), while the second part evaluates a wider range of quantitative and qualitative information through a judgment-based scoring model, which is linked to the aforementioned qualitative features of risk reporting. Consequently, the evaluation process of the second part of the methodology is much more complex than the first one.

With respect to the first part of the scoring model, the maximum score a bank can obtain is 30 . As for the second part of the scoring model, the maximum score is 235 . We assign equal weight to each section of the first and second part of the scoring model. Lastly, we rescaled the summed scores in order to express the final score (disclosure quality index) on a 0-100-point scale. The use of a common scale makes it easier to interpret final scores in our scoring model.

In order to increase the reliability of our evaluations, we conducted the empirical research separately, and after having assigned a score to each disclosure parameter in the scoring model we compared the final results. If one had assigned a score differently from the other, we compared these differences in order to explain the reasons behind the mismatching evaluation. The final decision is taken by comparing and assigning a shared evaluation of the disclosure parameters of the scoring model. Nonetheless, the subjectivity can be reduced but not entirely eliminated, as it is an unavoidable feature of content analysis and of any judgement-based scoring model.

Apart from the unavoidable level of subjectivity, we acknowledge another caveat of the methodology we propose: it is very time consuming and it requires considerable effort to be implemented correctly. However, we lay the foundation for additional methodologies by identifying the most relevant aspects researchers should analyze. Our approach could be also a useful starting point for automated computer assisted content analyses, although we think that "notwithstanding major advances in the use of computers, their application usually sacrifices the criterion of meaningfulness in favor of reliability and speed" [90]. In this regard, we wish to remark the importance of meaningfulness over speed, which is among the most relevant advantages of the approach we propose.

\section{Research findings: potential implications}

This section of the paper aims at discussing the research findings of our empirical study, and draws preliminary conclusions about credit risk disclosure in banking, which require further investigations to be confirmed by future research.

Despite the fact that Italian banks are subject to homogeneous regulatory requirements and accounting standards, we find several differences in bank credit risk disclosure. Overall, the research findings show that the credit risk disclosure has improved from 2012 to 2017 for all banks of the sample (see Table 5 and "Appendix" for details), and there is a high comparability of disclosure, especially over time. We did not observe any radical enhancement between two subsequent years, but taking into account the whole time horizon, there have been quite relevant improvements. Furthermore,

Table 5 An overview of the credit risk disclosure quality indexes

\begin{tabular}{|c|c|c|c|c|c|c|c|c|c|}
\hline & 2012 & 2013 & 2014 & 2015 & 2016 & 2017 & Mean & $\begin{array}{l}\text { Standard } \\
\text { deviation }\end{array}$ & Diff. 2017-2012 \\
\hline Unicredit & 62.29 & 63.76 & 64.41 & 66.48 & 69.93 & 71.40 & 66.38 & 3.30 & 9.11 \\
\hline Intesa Sanpaolo & 60.12 & 60.12 & 61.67 & 61.79 & 64.23 & 65.69 & 62.27 & 2.06 & 5.57 \\
\hline Monte dei Paschi di Siena & 51.13 & 53.17 & 55.86 & 55.36 & 57.30 & 58.47 & 55.21 & 2.46 & 7.34 \\
\hline Banco Popolare & 53.57 & 53.62 & 56.18 & 55.99 & 57.86 & 60.61 & 56.30 & 2.44 & 7.04 \\
\hline UBI Banca & 49.06 & 50.31 & 51.60 & 52.42 & 53.13 & 55.30 & 51.97 & 2.00 & 6.23 \\
\hline Banca Nazionale del Lavoro & 35.25 & 36.77 & 38.39 & 38.78 & 39.97 & 43.49 & 38.78 & 2.59 & 8.24 \\
\hline Mediobanca & 33.46 & 33.76 & 34.67 & 36.46 & 39.20 & 45.84 & 37.23 & 4.31 & 12.38 \\
\hline BPER Banca & 39.83 & 40.91 & 43.75 & 45.03 & 48.50 & 49.24 & 44.55 & 3.51 & 9.41 \\
\hline Banca Popolare di Milano & 46.49 & 48.34 & 44.91 & 47.14 & 49.14 & N/A & 47.20 & 1.47 & 2.65 \\
\hline Banca Popolare di Vicenza & 42.97 & 44.83 & 47.10 & 47.60 & 49.52 & N/A & 46.40 & 2.28 & 6.55 \\
\hline Mean & 47.42 & 48.56 & 49.85 & 50.70 & 52.88 & 56.25 & 50.63 & & \\
\hline Standard deviation & 8.83 & 8.76 & 8.85 & 8.65 & 8.85 & 8.59 & 8.66 & & \\
\hline
\end{tabular}


the research findings show that there is room to improve several aspects of credit risk disclosure. The following subsections focus on the theoretical and policy implications of the research findings of our exploratory analysis.

\section{Key disclosure issues: definitions, explanations, narrative, and graphic descriptions}

The first part of the scoring model is characterized by a high variability of final scores among the banks of the sample. There are banks that assign a great strategic importance to the comprehensibility and clarity of the credit risk reporting, while others underestimate the importance of providing definitions and explanations of their credit risk measures. A narrative explanation of the main credit risk parameters, results, and calculations, as well as a graphic descriptions of the main credit risk profiles, is fundamental, especially for nonprofessional users. Precise risk descriptions should adequately represent bank activities, credit risk exposures, credit risk drivers, credit risk methodologies, and how banks identify, measure, and manage credit risk. Credit risk reporting should be well organized, so that key information is prioritized and easy to find, and supported by charts, graphs, and cross-references. In this regard, comprehensibility enables stakeholders to understand bank credit risk position and credit risk management operations.

A well-structured glossary (either in the Notes or, in the Pillar 3 disclosure report) plays an important role for the comprehensibility of credit risk disclosure. We noticed there are some financial institutions that prefer to provide only an English version of such key terms or parameters, while other banks provide both versions. The glossary should provide a clear and synthetic definition of all specialized terms concerning credit risk measurements, parameters, and results. Some of them are provided in English only, even though the glossary should also provide their Italian translation (such as expected and unexpected loss, credit risk weighted assets, back-testing results, credit risk components).

Nearly all banks of the sample achieve a low final score in the "Literature review on risk disclosure" section of the first part of the scoring model (calculations and limitations). It emerges that they prefer not to disclose some information related to the limitations of their risk measurement approach, with particular reference to expected and unexpected loan loss, loss provisioning, potential credit risk exposures, internal credit rating, credit-risk-weighted assets. Notably, the disclosure of the methodologies that support these calculations is poor. This might be due to an underreporting strategy $[79,80]$, which affects the comprehensibility of the information provided.

The information on stress test results changes frequently over time. We often noticed that while in 1 year a bank provides information on stress test results in the Notes, the year after the same information is provided in the Management Commentary and again, the year after, no information on stress test results is reported at all. This variability of the disclosure negatively affects the comparability over time and over space, making it difficult to compare the credit risk profiles of different banks. Financial institutions should reduce such disclosure instability and provide homogeneous information on stress test results.

As for the risk-adjusted performance indicators, most banks of the sample report this information with reference to management compensation issues only.

\section{Key aspects of credit risk management in banking}

The second part of the disclosure scoring model focuses on the critical dimensions of bank credit risk management system. On closer inspection, the explanation of bank credit risk management strategies requires: the disclosure of expected management scenarios, expected economic and financial conditions, risk propensity, and emphasis on how credit risk can affect bank management decisions and performance. The explanation of bank credit risk management requires: the disclosure of risk management goals, procedures, processes, and policies; a description of the main results of the credit risk management function; an analysis of the key drivers of bank credit risk and their impact on funding, investing decisions and results; an explanation of the credit risk mitigation/transfer instruments used and policies adopted; information on the nature and purpose of loan securitization operations; a description of the relationship between credit risk management and bank general risk management issues. In this respect, it is necessary to provide information on the integration of credit risk management goals, procedures, processes, and policies. Furthermore, an adequate disclosure on hedging strategies is crucial for assessing whether a bank is really protected against credit risk.

A proper explanation of credit risk measurements requires the description of: credit risk components, credit risk exposures; credit risk measurement methodologies; underlying assumptions used to quantify credit risks; expected and unexpected credit losses; risk tolerance and risk propensity; and an illustration on how the credit risk measurement impact on corporate and lending strategy, bank performance, capital adequacy, current and expected credit exposures.

Our results show that all banks of the sample have enhanced the quality and quantity of credit risk management disclosure (sections 'A', 'B', and ' $E$ ' of the second part of the metric). Over the period analyzed, bank disclosure tended to focus more on the critical dimensions of credit risk strategy, hedging and securitization policies, internal control systems, credit risk measurements and expected results. However, the disclosure on current on-balance sheet credit risk exposures is more informative than that on potential and off-balance 
sheet credit risk exposures. The information on these aspects would require some enhancement.

The disclosure on non-performing loans improved from both a qualitative and a quantitative point of view. More specifically, financial institutions disclosed more details on the following aspects: non-performing exposures; strategies and policies to manage these risky assets; loan securitization operations based on non-performing loans; management of non-performing loans and its impacts on current and potential economic and financial performance.

The research findings highlight that the combination of qualitative and quantitative information may be not sufficiently informative. Financial institutions tended to provide information on risk measurement that are merely based on accounting results, or computed for bank regulatory purposes. If credit risk measures and other quantitative data are not adequately supported by qualitative information, the disclosure could become uninformative for a complete comprehension of bank exposure to credit risk. In this regard, the research findings support the idea that that qualitative disclosure is essential to shed additional light on quantitative disclosure, and to explain credit risk measurements, methodologies and results.

In conclusion, our research findings show that the banks of the sample did not adequately disclose information on their internal estimate of economic capital for credit risk. Financial institutions payed more attention to the credit risk capital adequacy adopting a regulatory perspective, rather than an internal and managerial approach.

\section{Fragmentation of credit risk disclosure}

The research findings show that the credit risk disclosure of the banks of our sample is affected by a certain degree of fragmentation. It is not perfectly organized, and it is distributed into different reports that are not adequately integrated and cross-referenced. Consequently, bank disclosure does not provide an integrated and unified viewpoint on risks, and particularly on credit risk.

We identify three different levels of disclosure fragmentation:

- Risk report level: this first kind of fragmentation is related to the existence of different risk disclosure documents (Notes, Pillar 3 disclosure report, and Management Commentary) characterized by different levels of detail, contents, and scopes. Those reports are often not sufficiently integrated or cross-referenced with each other and they are characterized by several instances of overlapping information;

- Credit risk level: this level of fragmentation is associated with the inadequate provision of a holistic view on key aspects of credit risk management decisions, credit risk exposures, credit risk components, credit risk measurements, credit risk mitigation/transfer instruments, loan portfolio, and risk capital requirements. The lack of an integrated perspective could compromise the understanding of the interaction of different credit risk factors, the potential impacts of changes of credit risk variables, the effectiveness of credit risk management strategies, policies and instruments, and their impacts on lending business, bank performance, capital and liquidity constraints;

- Bank level: this kind of fragmentation is related to the lack of an adequate analysis and explanation of the interconnectedness and interactions among different kinds of risk.

The disclosure of all banks of the sample is characterized by these three levels of fragmentation, to some extent. This fragmentation reduces the capability of the users to assess the implications of the credit risk in the bank economics and management.

In order to enhance the provision of an integrated view on credit risk and, in a wider perspective, on banking risks, it would be advisable:

- A better integration between the different risk reports, or the provision of a single risk report that provides a coherent and global explanation of bank risks. This expedient would eliminate the information overlapping between the risk disclosure documents;

- A reduction of the disclosure volume, an increase of its desirable attributes (comprehensibility, relevance, and materiality), and a provision of a parsimonious presentation, in order to make risk disclosure less burdensome. It is fundamental to tackle this problem, as we observed an increasing risk reporting volume over years for almost all banks of the sample (see Table 2 for further details). and the disclosure fragmentation is positively associated with the volume of risk reporting. The excessive details on credit risk, the high number of pages of credit risk reporting and the lack of summary reports and crossreferences do not allow the reader to have unified view on credit risk in banking;

- A provision of different levels of complexity of the risk reporting, in order to balance the trade-off between the level of detail of the information on the one hand, and the information needs of the different types of stakeholders on the other;

- A provision of a summary report with key indicators and cross-references, in order to synthesize bank credit risk exposures, key credit risk management decisions, and their impacts on bank performance;

- An adequate use of graphs and charts could reduce the complexity of the analysis, provide an integrated perspective on credit risk, support the comparison between 
different financial institutions, and synthetize key concepts, measures and results;

- A provision of overview sections that contain all the important information that stakeholders may need;

- A provision of an adequate explanation of the distinctive credit risk components and factors; structure of loan portfolio (composition, correlation, concentration); loan losses and measurement models; credit risk exposures; capital adequacy requirements, and key credit risk management decisions, as well as their interdependencies, and the current and potential impacts of credit risk factors fluctuations on risk management strategies, policies, and performance.

These proposals would enhance the informative value of bank credit risk disclosure, and offer an holistic view of the bank risk management and position. The adoption of a holistic disclosure should support stakeholders to evaluate bank credit risk exposures, how effectively these exposures are managed, and their effects on current and expected bank performance. Indeed, banking authorities and accounting standard setters have been assigned growing contents and scopes to risk reporting, at national and international level. Basel Committee on Banking Supervision [81, 82] has recently expanded risk disclosure requirements under Pillar 3 to strengthen market discipline. Nonetheless, the regulatory framework concerning credit risk reporting in banking is still extremely fragmented. Furthermore, although bank credit risk disclosure has improved over the last years, its complexity has likewise increased. Further efforts are necessary to manage the trade-off between the growing complexity of risk reporting and the provision of a holistic view.

\section{Backward-looking versus forward-looking credit risk disclosure}

The research findings show that the credit risk disclosure of the banks of our sample is much more backward-looking than forward-looking. These financial institutions provide a low level of information on potential credit risk exposures, stress tests, scenario analysis, sensitivity analysis, expected capital absorption capacity, potential credit risk management strategies and policies. Consequently, it is not possible to assess their potential credit risk exposures, and to know the real capacity of the bank to bear further credit risk. In addition, the predominant backward-looking perspective of credit risk disclosure does not enable a connection to be made between bank business strategies, strategic and risk management aims, and expected performances with capital needs and capacity to bear additional risks.

From 2015 to 2017, the research findings show that the forward-looking perspective improved in different sections of credit risk reporting, mainly because of the implementation process of the new accounting principle IFRS 9, a more precise description of stress test results and an enhancement of the sensitivity analysis. The analysis of potential impacts of the IFRS 9 enhanced the forward-looking information on bank credit risk, with particular reference to the following aspects: rating quantification; migration risk; insolvency risk; recovery risk; provisioning for loan losses; potential credit risk exposures assessment; implications of internal credit rating for bank management; analysis of non-performing loans. The implementation process and the forward-looking approach of the IFRS 9 contributed to improve the disclosure of the aforementioned credit risk aspects.

We suggest the following proposals to enhance the forward-looking perspective of bank credit risk:

- A higher degree of qualitative and quantitative disclosure on future scenarios of business and competitive positions, as well as more information on bank management and credit risk management strategies;

- Disclosure of an integrated and dynamic analysis of credit risk components, credit risk exposures, bank loan portfolios, economic and regulatory capital adequacy;

- Disclosure of a sensitivity and scenario analysis to demonstrate the effects of the variation of credit risk drivers on selected credit risk exposures, main underlying assumptions of credit risk assessment methodologies, estimation of expected and unexpected credit risk losses, capital adequacy, and bank performances. Most banks of the sample provide sensitivity and scenario analysis for market risk, but not for credit risk;

- Disclosure on the expected dynamics of bank lending strategies and policies, and their potential impacts on credit risk assumption, retention, prevention, protection, avoidance, and transfer;

- Provision of more stable, homogeneous, and comparable information on stress test results and their impacts on bank strategic decisions, potential credit risk exposures (on- and off-balance sheet), credit risk losses, economic and financial performances. We found that the disclosure on stress tests changes significantly over time and across banks;

- Provision of a complete analysis of the expected management decisions to be implemented to ensure bank capital adequacy on credit risk over time;

- Disclosure on the expected capacity of bank capital to bear further risks;

- Employment of key risk-adjusted performance indicators;

- Disclosure on the connections between risk-adjusted performance indicators and the generation of economic value; 
- Provision of a complete and informative analysis of the bank loan portfolio composition, correlation, and concentration;

- Provision of a complete and informative analysis of the expected fluctuations of credit risk components: insolvency risk, recovery risk, migration risk;

- Disclosure of the internal estimate of the economic value of bank capital for credit risk with reference to managerial and credit risk management purposes;

- Disclosure on the current and potentially large credit risk exposures;

- Provision of a complete analysis of hedged and unhedged credit risk exposures;

- Disclosure on expected credit risk exposures related to off-balance sheet positions;

- Provision of a meaningful disaggregation of current and expected credit risk exposures;

- Provision of a complete analysis of the bank credit risk transfer strategy and its impacts on bank insolvency and liquidity risk.

In sum, we argue that a more forward-looking perspective would improve bank credit risk disclosure and allow investors to adopt a longer-term perspective in their decision making processes, even though predicting the future is difficult, mainly because of an inherent uncertainty.

\section{The current and potential role of the Management Commentary in bank credit risk disclosure}

The Management Commentary is a mandatory report, intended to complement and supplement the annual financial statements. This document might overcome the limitations of bank financial statement, and improve user's ability to make better economic and financial decisions. However, our exploratory analysis shows that banks do not exploit all the potentiality of the Management Commentary. For many banks in the sample, the Management Commentary does not add any insight on credit risk in banking, and it does not enhance the provision of an integrated perspective on credit risk.

Bank management should exploit the communication potentials of the Management Commentary, to enhance the strategic and management perspective on credit risk, and the capacity of risk disclosure to represent the overall risk position in banking. From our exploratory empirical analysis, we can derive some policy implications for bank management, banking regulators, and accounting standard setters:

- Put more emphasis on longer-term strategic prospects;

- More focus on the connections between bank business model, strategy, credit risk management, and bank performance;
- A better explanation of current credit risk exposures in connection with bank risk strategy, business models, and operating environment;

- Provide meaningful qualitative and quantitative information on the operational position of the bank business, the factors affecting its future development, and the impacts on assumption, prevention, and transfer of credit risk;

- Provide a complete explanation of current and expected bank financial and economic performance focused on short-term and long-term credit risk exposures (on- and off- balance sheet);

- Provide a discussion on credit risk management strategies and policies and their implications for future bank performance;

- Provide a comprehensive analysis of potential risk impacts on future bank performance. More specifically, the Management Commentary could provide information on the risks that are not compulsorily reported in the financial statements (e.g. strategic risk, commercial risk, operational risk, reputational risk, and so forth);

- Illustrate the interdependence between credit risk and other risks;

- Provide a complete explanation of bank financial and non-financial expectations, with particular reference to credit risk;

- Illustrate the interdependence between bank business progress, lending strategy and policy, and their implications for current and future credit risk exposures;

- Provide a meaningful management view of future bank financial and non-financial outcomes, including the credit risk factors that drive them.

In sum, the Management Commentary shows an evident forward-looking approach. It may potentially offer an integrated disclosure perspective on bank risk strategies, risk management, risk measurement, and internal risk controls, enhancing credit risk disclosure quality.

Unfortunately, the Management Commentary is affected by a lack of standardization with potential negative consequences in terms of comparability (both across banks and over time) and latent semantic dimensions of the texts. We found substantial differences in communication and writing style of the Management Commentary. The current accounting rules impose a minimum content of the document, but they do not provide any specific configuration or structure. In 2010, the IASB issued the Management Commentary Practice Statement that provides a broad, non-mandatory framework for the presentation of the Management Commentary. This Practice Statement does not issue specific disclosure or prescribe detailed standards. It focuses on what is relevant to the unique circumstances of the business: historical financials, business descriptions, management information and market data, management perspectives [83, 84]. 
Thus, except for the minimum content imposed by current accounting rules, the structure, the narrative explanation and illustration, and the level of details is at bank management complete discretion. Consequently, the credit risk disclosure in the Management Commentary might not be adequately comparable and might suffer from lack of details. In addition, by using complex, ambiguous, and vague narrative structures, the Management Commentary may hide the bad performance of bank management, increasing bank opacity, and causing a misperception about credit risk. Information has to be truthful, timel,y and material. The predominance of disclosure on generic risk management policies and a generalized lack of coherence of the risk narrative might imply that annual report users could not be able to adequately evaluate bank credit risk exposures. More information is not always needed and it does not necessarily imply an increase in information transparency.

\section{Correlation-based network analysis of bank credit risk disclosure}

The content analysis methodology we propose can be used for numerous purposes, if combined with quantitative techniques. In this section, we provide an example of how the results of our metric can be used to provide preliminary evidences on the trend of bank credit risk disclosure over time.

In order to assess whether and to what extent bank credit risk disclosure scores follow a similar trend over time, the correlation-based network analysis is one of the most reliable and powerful statistical tool (for further information on network analysis see Barabàsi [85]). The analysis carried out is explained below. First of all, we computed the correlation matrix of bank total scores (Table 6). An important point to notice is that all the Pearson's correlation coefficients are positive and all of them, but the ones related to Banca Popolare di Milano, are high (above 0.8). Banca Popolare di Milano can be considered an exception because it is the only bank which is not characterized by an always increasing score over time. Through this matrix, it is possible to create a network where banks are the nodes and the correlations represent the links. However, since all bank scores are somehow correlated, it would be useless to create a network taking into account all correlations. It is much more useful to create a statistically validated network which excludes the nonsignificant correlation coefficients. Under the strong assumption of scores independently and normally distributed, it is possible to compute a two sided $t$ test with a $95 \%$ confidence interval in order to verify the statistical significance of each correlation coefficient. The statistically validated correlations constitute the links of the network.

Broadly speaking, two different approaches can be identified for creating a statistically validated network. The first one is the 'traditional approach' which considers each test as a stand-alone test and sets the confidence level at 1- $\alpha$ for each of them. The second approach is the 'family-wise error rate approach' also known as Bonferroni method. It takes into account the statistical significance of the network as a whole, setting the confidence level at:

$1-[\alpha /($ number of tests of the procedure $)]$

This procedure guarantees that the probability of wrongly rejecting at least one null hypothesis of no correlation is less or equal to $\alpha$. This second approach is more appropriate than the traditional one because we need to control the type one error of the whole procedure, even though it is a very conservative approach [86].

In order to apply these two approaches, it is necessary to compute a $t$ test for each correlation coefficient in Table 6. Table 7 shows the $t$ test matrix of banks' score correlation coefficients.
Table 6 Correlation matrix of banks' total scores

\begin{tabular}{lllllllllll}
\hline & UNI & ISP & MPS & BAP & UBI & BNL & MEB & BPE & BPM & BPV \\
\hline UNI & 1 & & & & & & & & \\
ISP & 0.975 & 1 & & & & & & & & \\
MPS & 0.915 & 0.921 & 1 & & & & & & & \\
BAP & 0.943 & 0.984 & 0.938 & 1 & & & & & & \\
UBI & 0.956 & 0.952 & 0.961 & 0.972 & 1 & & & & \\
BNL & 0.943 & 0.957 & 0.945 & 0.981 & 0.992 & 1 & & & \\
MEB & 0.934 & 0.955 & 0.832 & 0.956 & 0.934 & 0.958 & 1 & & & \\
BPE & 0.979 & 0.97 & 0.961 & 0.952 & 0.961 & 0.936 & 0.884 & 1 & & \\
BPM & 0.581 & 0.386 & 0.194 & 0.181 & 0.302 & 0.282 & 0.543 & 0.381 & 1 & \\
BPV & 0.929 & 0.927 & 0.987 & 0.962 & 0.992 & 0.999 & 0.905 & 0.977 & 0.299 & 1 \\
\hline
\end{tabular}

The acronyms adopted are the followings: UNI (Unicredit), ISP (Intesa Sanpaolo), MPS (Monte dei Paschi di Siena), BAP (Banco Popolare), UBI (UBI Banca), BNL (Banca Nazionale del Lavoro), MEB (Mediobanca), BPE (BPER Banca), BPM (Banca Popolare di Milano), and BPV (Banca Popolare di Vincenza) 
Table $7 T$ test matrix of banks' score correlation coefficients

\begin{tabular}{|c|c|c|c|c|c|c|c|c|c|c|}
\hline & UNI & ISP & MPS & BAP & UBI & BNL & MEB & BPE & BPM & BPV \\
\hline \multicolumn{11}{|l|}{ UNI } \\
\hline ISP & $\underline{8.82}$ & & & & & & & & & \\
\hline MPS & $\underline{4.54}$ & $\underline{4.74}$ & & & & & & & & \\
\hline BAP & $\underline{5.66}$ & $\underline{11.13}$ & $\underline{5.44}$ & & & & & & & \\
\hline UBI & $\underline{6.56}$ & $\underline{6.25}$ & $\underline{6.99}$ & $\underline{8.24}$ & & & & & & \\
\hline BNL & $\underline{5.65}$ & $\underline{6.59}$ & $\underline{5.77}$ & $\underline{10.18}$ & $\underline{15.31}$ & & & & & \\
\hline MEB & $\underline{5.25}$ & $\underline{6.43}$ & $\underline{2.99}$ & $\underline{6.49}$ & $\underline{5.23}$ & 6.7 & & & & \\
\hline BPE & $\underline{9.54}$ & $\underline{7.95}$ & $\underline{6.95}$ & $\underline{6.23}$ & $\underline{6.96}$ & $\underline{5.32}$ & $\underline{3.79}$ & & & \\
\hline BPM & 1.43 & 0.84 & 0.4 & 0.37 & 0.63 & 0.59 & 1.29 & 0.82 & & \\
\hline BPV & $\underline{5.01}$ & $\underline{4.95}$ & $\underline{12.2}$ & $\underline{7.05}$ & $\underline{15.45}$ & 36.99 & $\underline{4.26}$ & 9.1 & 0.63 & \\
\hline
\end{tabular}

In Table 7, the values non-underlined are those that are not statistically significant under the traditional approach, with a confidence level of $5 \%$. They are those related to Banca Popolare di Milano only, for the reasons explained above. The underlined values are significant under the 'traditional approach' and the bolded and underlined values are significant under the 'Bonferroni approach'. Based on such results, it is possible to create a statistically validated network of bank score correlations. In short, it is a network where only the significant correlation coefficients are drawn as links between two banks. In order to increase the reliability of our network analysis, only the links validated through the Bonferroni approach are drawn (the most conservative approach).

In order to show the relationships between bank scores and bank size, the dimension of the circles of the nodes in Fig. 1 represents their total asset figures (at 31 December 2017).

The first thing to notice from this picture is that Intesa San Paolo and Unicredit are highly correlated. They are the largest banks in the sample. It is reasonable to assume that they should have better capabilities of adjusting their reporting model in order to fulfil regulatory requirements and investors' needs of information. Moreover, large banks tend

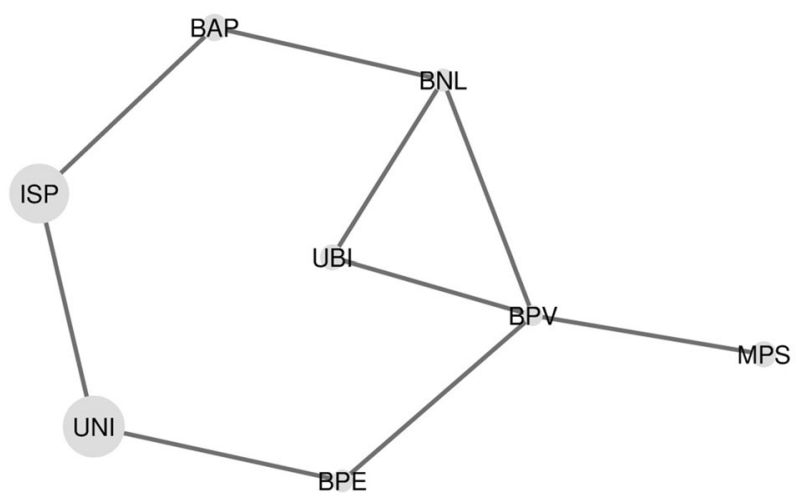

Fig. 1 Statistically validated network of banks' score correlations to operate in more sectors than smaller ones, and therefore their financial reporting should reasonably provide information on a wider range of topics. Hence, it is clear that the evolution of large bank risk reporting over time is different from that of the other smaller financial institutions. According to these explanations, it might be the case that banks of similar dimensions tend to react more or less uniformly to external stimuli, such as changes in the regulatory framework or shareholders and stakeholders' concerns.

A second point of observation is that Banca Nazionale del Lavoro with three links and Banca Popolare di Vicenza with four links are the most connected banks. They are both medium-sized financial institutions. This might be one of the reasons why they are so connected. Furthermore, there are two banks which are not present in this network, namely Banca Popolare di Milano and Mediobanca. Banca Popolare di Milano does not belong to this network because of the aforementioned issues of its reporting model. As for Mediobanca, it is a bank different from the others of the sample, because of the peculiarity of its business model. More specifically, it is close to an investment banking model rather than a commercial banking one. ${ }^{2}$ Thus, it is reasonable to assume that its risk exposure is different from that of the other banks and its disclosure practices differ accordingly. As such, the evolution of its credit risk reporting is influenced by determinants that are partially different from those of the other financial institutions of the sample.

Unfortunately, this analysis is affected by the assumptions of scores normally and independently distributed, which is a strong assumption. In order to address this concern, we carry out a robustness test. Another option to assess the statistical significance of the correlation coefficients without any assumption on score distribution is based on the permutations of bank scores over time (i.e., the rows of Table 5). First of all, it is necessary to create a certain number of

\footnotetext{
${ }^{2}$ For further information see https://www.mediobanca.com/en/ourgroup/business-model.html.
} 
Table 8 Matrix of Ps after $10^{6}$ casual permutations

\begin{tabular}{lllllllllll}
\hline & UNI & ISP & MPS & BAP & UBI & BNL & MEB & BPE & BPM & BPV \\
\hline UNI & & & & & & & & & & \\
ISP & $\underline{0.028}$ & & & & & & & & & \\
MPS & 0.052 & $\underline{0.04}$ & & & & & & & & \\
BAP & $\underline{0.049}$ & $\underline{0.015}$ & $\underline{0.019}$ & & & & & & & \\
UBI & $\underline{0.036}$ & 0.05 & $\underline{0.018}$ & $\underline{0.036}$ & & & & & & \\
BNL & $\underline{0.041}$ & $\underline{0.047}$ & $\underline{0.005}$ & $\underline{0.031}$ & $\underline{0.005}$ & & & & & \\
MEB & $\underline{0.007}$ & $\underline{0.026}$ & $\underline{0.047}$ & 0.052 & $\underline{0.049}$ & 0.07 & & & & \\
BPE & $\underline{0.013}$ & $\underline{0.01}$ & $\underline{0.03}$ & $\underline{0.013}$ & $\underline{0.017}$ & $\underline{0.015}$ & $\underline{0.012}$ & & & \\
BPM & 0.196 & 0.296 & 0.399 & 0.411 & 0.351 & 0.366 & 0.219 & 0.3 & & \\
BPV & $\underline{0.024}$ & $\underline{0.025}$ & $\underline{0.012}$ & $\underline{0.014}$ & $\underline{0.006}$ & $\underline{0.002}$ & $\underline{0.021}$ & $\underline{0.012}$ & 0.348 & \\
\hline
\end{tabular}

casual permutations of the scores over time, and after that to recalculate the correlation matrix for each permutation. Lastly, it is possible to compute the probability ' $\mathrm{P}$ ' of obtaining a correlation which is greater than that observed as the number of times that the correlation obtained through the simulation is greater than the true observed value, divided by the number of permutations. Formally:

\section{$P=($ number of times that correlation $>$ observed value $) /$ number of permutations}

The greater the number of permutations, the more accurate the estimation. We computed one million permutations. It should be satisfactory for making the estimations reliable enough.

Table 8 is the matrix of Ps after one million casual permutations. The underlined values are those below 5\%, and therefore they can be considered statistically significant. This table is useful as a robustness check, because we can observe that all the correlation coefficients we used to draw the links of the statistically validated network (Fig. 1) are still significant under this approach (i.e. their values are less than 0.05). We could have used the 'Bonferroni approach', but it would be too conservative in this instance (notice that no $P$ is less than $0.05 / 45 \%$ ). Ultimately, despite not being as strong a reinforcement as the one provided by the 'Bonferroni approach', this robustness test provides support on the preliminary conclusions we drew from this analysis.

Another useful way to study this network is to create a minimum spanning tree. It is a natural choice to analyze this kind of relationship. It is the shortest tree connecting all the elements in a single graph. One of the simplest algorithms to create the minimum spanning tree is the Kruskal's algorithm [87], which consists of three steps. First of all, it requires to sort the links (i.e. the correlation coefficients) with respect to their weights. After that, it is necessary to start adding links to the tree from the link with the largest weight until the link with the smallest weight. However, only links which do not form a cycle must be added. In other words, only links which connect disconnected components of the network must be considered (Fig. 2).
Figure 2 represents the bank score minimum spanning tree. It provides some interesting insights. Mediobanca and Banca Popolare di Milano are at the extreme periphery of the network. This confirms the results obtained through the previous analyses. Furthermore, the minimum spanning tree provides further evidence on the fact that banks of similar dimensions follow a similar evolution over time in terms of credit risk disclosure. For instance, an important aspect to notice in Fig. 2 is that, roughly speaking, the larger the bank, the farther it is from the center of the network. In order to show that this statement holds true, the sample is divided into two groups: the five largest banks are considered as 'large banks', whereas the other five are considered 'less large banks'. As Table 9 shows, large banks are located at the periphery of the network (notice that the average number of links of the five largest banks of the sample is 1.4), while the other smaller banks of the sample are in a more central zone (the average number of links of the five smallest banks of the sample is 2.2 and excluding the Banca Popolare di Milano and Mediobanca that can be considered two exceptions, it rises at 3).

Thus, it appears that the common evolution of the risk disclosure of 'less large banks' is more pronounced than that of 'large banks'. A possible explanation of this finding is related to the fact that large banks are able to design their risk reporting model more autonomously because of their ability to attract or develop

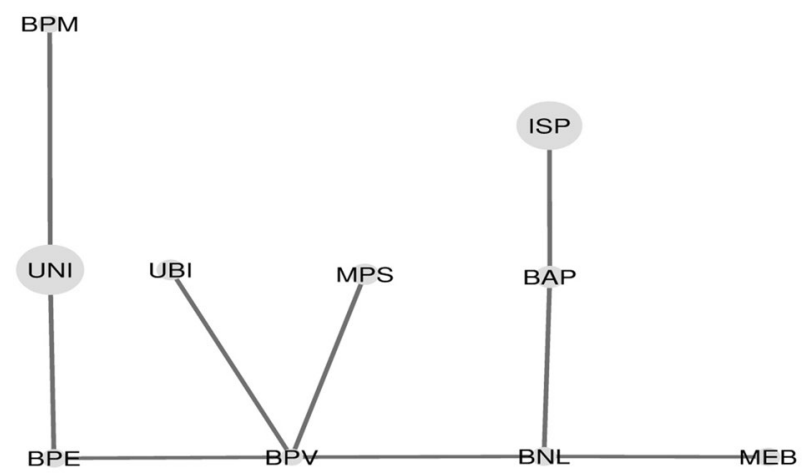

Fig. 2 Banks' score minimum spanning tree 
Table 9 Descriptive statistics of the minimum spanning tree

\begin{tabular}{lllll}
\hline Bank & Large/small & Size (total assets) & $\begin{array}{l}\text { Number } \\
\text { of links }\end{array}$ & Other information \\
\hline UNI & Large & 836,790 & 2 & Large banks' average number of links \\
ISP & Large & 796,861 & 1 & 1.4 \\
MPS & Large & 139,154 & 1 & Less large banks' average number of links \\
BAP & Large & 161,207 & 2 & 2.2 \\
UBI & Large & 127,376 & 1 & Less large banks' average number of links \\
& & & & (excluding MEB \& BPM) \\
BNL & Less large & 78,934 & 3 & 3 \\
MEB & Less large & 70,446 & 1 & Large banks' size coefficient of variation \\
BPE & Less large & 71,339 & 2 & 0.802 \\
BPM & Less large & 51,131 (at 31/12/2016) & 1 & Less large banks' size coefficient of variation \\
BPV & Less large & 34,424 (at 31/12/2016) & 4 & 0.265 \\
\hline
\end{tabular}

internally a proper know-how in terms of risk reporting for the preparation of their financial statements. Hence, their reactions to external events in terms of change in their credit risk disclosure practices might differ accordingly. In contrast, 'less large banks' may not able to create a completely autonomous risk reporting model, and therefore they tend to react similarly, trying to understand first the behavior of the other financial institutions, and only after that they take a decision. As a result, the trend of their credit risk disclosure is more pronounced than that of 'large banks'. Other elements which support this interpretation are the coefficient of variation of banks' size (Table 9) whose values are different for 'large banks' (0.802) and 'less large banks' (0.265). Since, the 'large banks' of the sample are more heterogeneous than the 'small banks' in terms of size, also the evolutions of 'large banks' risk reporting models are less similar to each other than those of 'small banks', and our results support this assumption. The last aspect to notice from Fig. 2 is that the link between Banca Popolare di Milano and Unicredit is the only one which is not statistically validated under the aforementioned traditional approach. This aspect supports the reliability of the statistical methodology employed.

In conclusion, the analyses carried out in this section provide evidence that bank credit risk disclosure provided by different banks follow a similar trend over time. In particular, it emerges that size plays a pivotal role in determining this common trend, because banks of similar dimensions follow a similar trend, which is particularly pronounced for 'small banks'. Furthermore, it emerges that bank business models might play a role in terms of the evolution over time of their risk reporting model. Different business models lead to different risk exposures, and therefore the risk disclosure adapts accordingly. It is clear that, this is just an hypothesis based on the results of one single bank (Mediobanca) out of the ten of our sample. More comprehensive analyses are required to confirm these results, and we leave to future research more in depth investigations. The main limitation of this analysis is related to the small dimension of the sample analyzed. However, considering that the different approaches lead to similar conclusions, and that the robustness test carried out supports our conclusions, this analysis can be considered reliable. Undoubtedly, further investigations are still necessary to confirm these results.

\section{Conclusion}

This paper proposes a methodological tool to analyze credit risk disclosure in bank financial reports, based on the content analysis framework described by Krippendorf [28]. We use this innovative methodology to provide empirical preliminary evidences on bank credit risk disclosure practices. Banking regulation and supervisors, international accounting standards, and financial market constraints have been pressuring banks to improve their credit risk disclosure practices. Risk disclosure requirements have arisen in many different countries. The ongoing financial crisis and the two pillars of the European banking union (the Single Supervisory Mechanism and the Single Resolution Mechanism) have remarked the importance of the credit risk disclosure in banking. Financial institutions are subject to a stronger market discipline and the enhancement of bank credit risk disclosure will contribute to a broader financial stability. Adequate and effective transparency of bank risk profiles also inspires a sense of trust in the banking industry by reducing the uncertainty of the bank risk assessment. A better knowledge of credit risk in banking enhances financial market transparency and stability, as well as market discipline, as remarked by the third pillar of the New Basel Capital Accord.

Our exploratory empirical analysis focuses on Italian banks. Although banks are subject to homogeneous regulatory requirements and accounting standards, their credit risk reporting is still characterized by some differences. By using our tailormade disclosure index, this research provides useful theoretical and policy implications, which need to be confirmed by more comprehensive analyses that could draw upon the methodology we propose and on our preliminary results. Although the international accounting standards and the bank regulatory requirements have contributed to enhance credit risk disclosure, we argue that there is still room for improvement of the disclosure 
and the transparency of the information, in order to strengthen the stability of the banking system and the effectiveness of market discipline.

Adopting a correlation-based network analysis approach, the paper also provides preliminary evidence on the existence of a relationship between credit risk disclosure, bank size and business model. More specifically, based on our results, we hypothesize that the enhancements of bank credit risk disclosure scores in the period 2012-2017 are related to bank size and business model. Also in this case, given the small sample analyzed, our results need to be confirmed by more comprehensive analyses.

The methodology we propose mitigates various concern about the subjective evaluation that affects the content analysis. The hybrid methodology we propose overcome the drawbacks of a purely quantitative or qualitative analysis. Furthermore, the structure of this hybrid methodology can be used as part of other research designs, with reference to other risk types and industries. After a rigorous identification of the key parameters associated with each risk type, this approach can be applied to investigate risk disclosure not only in banking but also in other fields. It can be used to analyze the effects of risk disclosure on bank performance and to identify the main determinants of bank risk disclosure, as content analysis is the most widespread, suitable, and reliable methodology to analyze qualitative and quantitative aspects of risk disclosure. Furthermore, our credit risk disclosure index may be used to analyze the relationship between disclosure and idiosyncratic risk, after controlling for systemic risk. In conclusion, the approach we propose in this paper could pave the way for future research and support researchers and analysts to extend our knowledge on this field of study, by providing them with a methodological tool to examine in depth credit risk disclosure in the banking industry.

Acknowledgements Open access funding provided by Università degli Studi di Palermo within the CRUI-CARE Agreement. We do gratefully thank Owen Powell (Bangor University) for his useful suggestions, and Prof. Michele Tumminello (University of Palermo) for his insightful guidance throughout the correlation-based network analysis.

Open Access This article is licensed under a Creative Commons Attribution 4.0 International License, which permits use, sharing, adaptation, distribution and reproduction in any medium or format, as long as you give appropriate credit to the original author(s) and the source, provide a link to the Creative Commons licence, and indicate if changes were made. The images or other third party material in this article are included in the article's Creative Commons licence, unless indicated otherwise in a credit line to the material. If material is not included in the article's Creative Commons licence and your intended use is not permitted by statutory regulation or exceeds the permitted use, you will need to obtain permission directly from the copyright holder. To view a copy of this licence, visit http://creativecommons.org/licenses/by/4.0/.

\section{Appendix}

See Tables 10, 11, 12, 13, 14, 15, 16, 17, 18 and 19 .
Table 10 Unicredit: results of the credit risk disclosure analysis. Sources: Unicredit, Relazioni e Bilancio, 2012, 2013, 2014, 2015, 2016, 2017 (it includes the Notes to the account, and the Management

\begin{tabular}{|c|c|c|c|c|c|c|}
\hline Unicredit 2012 & Score & 2013 & 2014 & 2015 & 2016 & 2017 \\
\hline \multicolumn{7}{|l|}{ First part of the scoring rule } \\
\hline Section 1 -Definitions & 6 & 6 & 5 & 7 & 7 & 7 \\
\hline Section $2-$ Calculations and limitations & 5 & 5 & 5 & 5 & 5 & 5 \\
\hline Section 3-Explanations & 6 & 6 & 6 & 6 & 6 & 6 \\
\hline Section 4-Other key disclosure parameters & 6 & 6 & 6 & 6 & 6 & 6 \\
\hline Total score of the first part & 23 & 23 & 22 & 24 & 24 & 24 \\
\hline \multicolumn{7}{|l|}{ Second part of the scoring rule } \\
\hline Section A-Key aspects of credit risk management in banking & 12 & 13 & 14 & 14 & 15.5 & 16 \\
\hline Section $\mathrm{B}-$ Credit risk management decision disclosure & 12 & 13 & 14 & 14 & 15.5 & 15.5 \\
\hline Section $\mathrm{C}-$ Credit risk components & 10 & 10.5 & 11 & 11 & 12 & 13 \\
\hline Section D-Information on credit risk exposures & 14 & 14 & 14.5 & 14.5 & 15 & 15 \\
\hline Section E-Loan losses and measurement models & 13 & 13.5 & 14 & 14 & 15 & 15 \\
\hline Section $\mathrm{F}$-Credit risk mitigation/transfer instruments & 13 & 13 & 13 & 13 & 13 & 13.5 \\
\hline Section $\mathrm{G}$-Other key elements of bank credit risk & 7.5 & 8 & 8 & 8.5 & 9.5 & 10 \\
\hline Section $\mathrm{H}-$ Bank loan portfolio disclosure & 9.5 & 9.5 & 10 & 10 & 10.5 & 10.5 \\
\hline Section $\mathrm{I}-$ Credit rating disclosure issues & 18 & 18.5 & 19 & 19 & 21 & 22 \\
\hline Section $\mathrm{L}-$ Bank credit risk capital requirements disclosure & 14 & 14.5 & 15 & 15 & 15 & 16 \\
\hline Section $\mathrm{M}-$ General credit risk disclosure issues & 9 & 9 & 9 & 9 & 10.5 & 10.5 \\
\hline Total score of the second part & 132 & 136.5 & 141.5 & 142 & 152.5 & 157 \\
\hline Final total score & 155 & 159.5 & 163.5 & 166 & 176.5 & 181 \\
\hline Normalized final total score & 62.29 & 63.76 & 64.41 & 66.48 & 69.93 & 71.40 \\
\hline
\end{tabular}

Commentary); Unicredit, Terzo Pilastro di Basilea 2. Informativa al Pubblico, 2012, 2013, 2014, 2015, 2016, 2017 (it includes the Pillar III Disclosures) 
Table 11 Intesa Sanpaolo: results of the credit risk disclosure analysis. Sources: Intesa Sanpaolo, Relazione e Bilancio, 2012, 2013, 2014, 2015, 2016, 2017 (it includes the Notes to the account, and the Management Commentary); Intesa Sanpaolo, Terzo Pilastro di Basilea 2. Informativa al Pubblico, 2012, 2013, 2014, 2015, 2016, 2017 (it includes the Pillar III Disclosures)

\begin{tabular}{|c|c|c|c|c|c|c|}
\hline Intesa Sanpaolo 2012 & Score & 2013 & 2014 & 2015 & 2016 & 2017 \\
\hline \multicolumn{7}{|l|}{ First part of the scoring rule } \\
\hline Section 1 -Definitions & 6 & 6 & 6 & 6 & 6 & 6 \\
\hline Section 2-Calculations and limitations & 4 & 4 & 4 & 4 & 4 & 4 \\
\hline Section 3-Explanations & 5 & 5 & 5 & 5 & 5 & 5 \\
\hline Section 4-Other key disclosure parameters & 4 & 4 & 5 & 4 & 5 & 5 \\
\hline Total score of the first part & 19 & 19 & 20 & 19 & 20 & 20 \\
\hline \multicolumn{7}{|l|}{ Second part of the scoring rule } \\
\hline Section A-Key aspects of credit risk management in banking & 12.5 & 13 & 13.5 & 13.5 & 14 & 14.5 \\
\hline Section $\mathrm{B}-$ Credit risk management decision disclosure & 12 & 12 & 12.5 & 13 & 13.5 & 13.5 \\
\hline Section $\mathrm{C}-$ Credit risk components & 10 & 10 & 10 & 10.5 & 11 & 11 \\
\hline Section D-Information on credit risk exposures & 15.5 & 15.5 & 15.5 & 15.5 & 16 & 16.5 \\
\hline Section E-Loan losses and measurement models & 12 & 12 & 13 & 13.5 & 14 & 14.5 \\
\hline Section $\mathrm{F}-$ Credit risk mitigation/transfer instruments & 12 & 12 & 12 & 12 & 12 & 12.5 \\
\hline Section G-Other key elements of bank credit risk & 9.5 & 8.5 & 8.5 & 9 & 10 & 10.5 \\
\hline Section $\mathrm{H}-$ Bank loan portfolio disclosure & 9.5 & 9.5 & 9.5 & 10 & 10 & 10.5 \\
\hline Section $\mathrm{I}-$ Credit rating disclosure issues & 19 & 19 & 19 & 20 & 20.5 & 21.5 \\
\hline Section L-Bank credit risk capital requirements disclosure & 13.5 & 14 & 14 & 14 & 14 & 15 \\
\hline Section $\mathrm{M}-$ General credit risk disclosure issues & 10.5 & 10.5 & 10.5 & 10.5 & 11 & 11 \\
\hline Total score of the second part & 136 & 136 & 138 & 141.5 & 146 & 151 \\
\hline Final total score & 155 & 155 & 158 & 160.5 & 166 & 171 \\
\hline Normalized final total score & 60.12 & 60.12 & 61.67 & 61.79 & 64.23 & 65.69 \\
\hline
\end{tabular}

Table 12 Monte dei Paschi: results of the credit risk disclosure analysis. Sources: Monte dei Paschi di Siena, Relazione e Bilancio, 2012, 2013, 2014, 2015, 2016, 2017 (it includes the Notes to the account, and the Management Commentary); Monte dei Paschi di Siena, Terzo Pilastro di Basilea 2. Informativa al Pubblico, 2012, 2013, 2014, 2015, 2016, 2017 (it includes the Pillar III Disclosures)

\begin{tabular}{|c|c|c|c|c|c|c|}
\hline Monte dei Paschi di Siena 2012 & Score & 2013 & 2014 & 2015 & 2016 & 2017 \\
\hline \multicolumn{7}{|l|}{ First part of the scoring rule } \\
\hline Section 1 -Definitions & 5 & 6 & 6 & 6 & 6 & 6 \\
\hline Section $2-$ Calculations and limitations & 2 & 1 & 1 & 1 & 1 & 1 \\
\hline Section 3-Explanations & 5 & 6 & 6 & 6 & 6 & 6 \\
\hline Section 4-Other key disclosure parameters & 4 & 4 & 5 & 4 & 5 & 4 \\
\hline Total score of the first part & 16 & 17 & 18 & 17 & 18 & 17 \\
\hline \multicolumn{7}{|l|}{ Second part of the scoring rule } \\
\hline Section A-Key aspects of credit risk management in banking & 11.5 & 12 & 13.5 & 13.5 & 13.5 & 13.5 \\
\hline Section B-Credit risk management decision disclosure & 11 & 12 & 12.5 & 12.5 & 13 & 14 \\
\hline Section $\mathrm{C}-$ Credit risk components & 7 & 7 & 7.5 & 8 & 8.5 & 9 \\
\hline Section D-Information on credit risk exposures & 10.5 & 11 & 11.5 & 11 & 11 & 11 \\
\hline Section E-Loan losses and measurement models & 13.5 & 13.5 & 13.5 & 11 & 11 & 11.5 \\
\hline Section $\mathrm{F}-$ Credit risk mitigation/transfer instruments & 10.5 & 11 & 11 & 11.5 & 12.5 & 13.5 \\
\hline Section $\mathrm{G}$-Other key elements of bank credit risk & 8 & 8 & 7.5 & 9.5 & 10.5 & 11.5 \\
\hline Section $\mathrm{H}-$ Bank loan portfolio disclosure & 8.5 & 8.5 & 8.5 & 8.5 & 8.5 & 9 \\
\hline Section $\mathrm{I}-$ Credit rating disclosure issues & 15.5 & 16 & 17.5 & 18.5 & 18.5 & 20 \\
\hline Section L-Bank credit risk capital requirements disclosure & 12 & 12 & 13 & 13 & 13 & 14 \\
\hline Section $\mathrm{M}-$ General credit risk disclosure issues & 8 & 8 & 8.5 & 8.5 & 8.5 & 8.5 \\
\hline Total score of the second part & 116 & 119 & 124.5 & 125.5 & 128.5 & 135.5 \\
\hline Final total score & 132 & 136 & 142.5 & 142.5 & 146.5 & 152.5 \\
\hline Normalized final total score & 51.13 & 53.17 & 55.86 & 55.36 & 57.30 & 58.47 \\
\hline
\end{tabular}


Table 13 Banco Popolare and Banco BPM: results of the credit risk disclosure analysis. Sources: Banco Popolare, Relazione finanziaria annuale, 2012, 2013, 2014, 2015, 2016 (it includes the Notes to the account, and the Management Commentary); Banco Popolare, Informativa al Pubblico. Pillar 3, 2012, 2013, 2014, 2015, 2016 (it

\begin{tabular}{|c|c|c|c|c|c|c|}
\hline Banco Popolare 2012 & Score & 2013 & 2014 & 2015 & 2016 & 2017 \\
\hline \multicolumn{7}{|l|}{ First part of the scoring rule } \\
\hline Section 1-Definitions & 5 & 5 & 5 & 5 & 5 & 5 \\
\hline Section $2-$ Calculations and limitations & 1 & 1 & 1 & 1 & 1 & 3 \\
\hline Section 3-Explanations & 6 & 6 & 6 & 6 & 6 & 6 \\
\hline Section 4-Other key disclosure parameters & 5 & 4 & 5 & 4 & 5 & 4 \\
\hline Total score of the first part & 17 & 16 & 17 & 16 & 17 & 18 \\
\hline \multicolumn{7}{|l|}{ Second part of the scoring rule } \\
\hline Section A-Key aspects of credit risk management in banking & 12.5 & 13 & 14 & 14 & 14 & 14 \\
\hline Section $\mathrm{B}-$ Credit risk management decision disclosure & 11.5 & 12 & 12 & 12.5 & 13 & 13.5 \\
\hline Section $\mathrm{C}-$ Credit risk components & 9.5 & 10 & 10 & 10.5 & 11 & 11.5 \\
\hline Section D-Information on credit risk exposures & 13 & 13 & 13 & 13 & 13.5 & 14 \\
\hline Section E-Loan losses and measurement models & 10 & 10 & 10 & 10.5 & 10.5 & 12.5 \\
\hline Section $\mathrm{F}-$ Credit risk mitigation/transfer instruments & 11.5 & 11.5 & 11.5 & 12 & 12 & 12 \\
\hline Section G-Other key elements of bank credit risk & 6.5 & 7 & 9.5 & 9.5 & 10 & 10.5 \\
\hline Section $\mathrm{H}-$ Bank loan portfolio disclosure & 9.5 & 9.5 & 9.5 & 9.5 & 9.5 & 9.5 \\
\hline Section $\mathrm{I}-$ Credit rating disclosure issues & 18.5 & 19 & 19.5 & 20 & 20 & 20.5 \\
\hline Section L-Bank credit risk capital requirements disclosure & 9.5 & 10 & 11 & 11 & 11 & 13 \\
\hline Section $\mathrm{M}-$ General credit risk disclosure issues & 8 & 8 & 8 & 8 & 8.5 & 9 \\
\hline Total score of the second part & 120 & 123 & 128 & 130.5 & 133 & 140 \\
\hline Final total score & 137 & 139 & 145 & 146.5 & 150 & 158 \\
\hline Normalized final total score & 53.57 & 53.62 & 56.18 & 55.99 & 57.86 & 60.61 \\
\hline
\end{tabular}

includes the Pillar III Disclosures); Banco BPM, Relazione finanziaria annuale, 2017 (it includes the Notes to the account, and the Management Commentary); Banco BPM, Informativa al Pubblico da parte degli enti. Pillar 3, 2017
Table 14 UBI Banca: results of the credit risk disclosure analysis. Sources: UBI Banca, Relazioni e bilanci, 2012, 2013, 2014, 2015, 2016, 2017 (it includes the Notes to the account, and the Management

\begin{tabular}{|c|c|c|c|c|c|c|}
\hline Ubi Banca 2012 & Score & 2013 & 2014 & 2015 & 2016 & 2017 \\
\hline \multicolumn{7}{|l|}{ First part of the scoring rule } \\
\hline Section 1-Definitions & 3 & 3 & 3 & 3 & 3 & 3 \\
\hline Section $2-$ Calculations and limitations & 2 & 2 & 2 & 2 & 2 & 2 \\
\hline Section 3-Explanations & 5 & 5 & 5 & 5 & 5 & 5 \\
\hline Section 4-Other key disclosure parameters & 5 & 5 & 5 & 5 & 5 & 5 \\
\hline Total score of the first part & 15 & 15 & 15 & 15 & 15 & 15 \\
\hline \multicolumn{7}{|l|}{ Second part of the scoring rule } \\
\hline Section A-Key aspects of credit risk management in banking & 14 & 14 & 14.5 & 15 & 15 & 16 \\
\hline Section B-Credit risk management decision disclosure & 12 & 13 & 13.5 & 13.5 & 13.5 & 14.5 \\
\hline Section $\mathrm{C}-$ Credit risk components & 7 & 7.5 & 8 & 8.5 & 8.5 & 9 \\
\hline Section D-Information on credit risk exposures & 9 & 9 & 9 & 9.5 & 10 & 11 \\
\hline Section E-Loan losses and measurement models & 8 & 8.5 & 9 & 9.5 & 10 & 10.5 \\
\hline Section $\mathrm{F}-$ Credit risk mitigation/transfer instruments & 10 & 10 & 11 & 11 & 11 & 12 \\
\hline Section G-Other key elements of bank credit risk & 10.5 & 11 & 11 & 11 & 11.5 & 12 \\
\hline Section $\mathrm{H}-$ Bank loan portfolio disclosure & 9 & 9 & 9 & 9 & 9 & 9 \\
\hline Section $\mathrm{I}-$ Credit rating disclosure issues & 16 & 17 & 17 & 17 & 17.5 & 18.5 \\
\hline Section L-Bank credit risk capital requirements disclosure & 8.5 & 9 & 10 & 10.5 & 11 & 11 \\
\hline Section $\mathrm{M}-$ General credit risk disclosure issues & 7.5 & 7.5 & 7.5 & 7.5 & 7.5 & 8 \\
\hline Total score of the second part & 111.5 & 115.5 & 119.5 & 122 & 124.5 & 131.5 \\
\hline Final total score & 126.5 & 130.5 & 134.5 & 137 & 139.5 & 146.5 \\
\hline Normalized final total score & 49.06 & 50.31 & 51.60 & 52.42 & 53.13 & 55.30 \\
\hline
\end{tabular}

Commentary); UBI Banca, Informativa al Pubblico. Pillar 3, 2012, 2013, 2014, 2015, 2016, 2017 (it includes the Pillar III Disclosures) 
Table 15 Banca Nazionale del Lavoro: results of the credit risk disclosure analysis. Sources: Banca Nazionale del Lavoro, Bilancio d'esercizio, 2012, 2013 (it includes the Notes to the account, and the Management Commentary); Banca Nazionale del Lavoro, Informa- tiva al Pubblico. Pillar 3, 2012, 2013 (it includes the Pillar III Disclosures); Banca Nazionale del Lavoro, Relazione finanziaria, 2014, 2015, 2016, 2017 (it includes the Notes to the account, the Management Commentary, and the Pillar III Disclosures)

\begin{tabular}{|c|c|c|c|c|c|c|}
\hline Banca Nazionale del Lavoro 2012 & Score & 2013 & 2014 & 2015 & 2016 & 2017 \\
\hline \multicolumn{7}{|l|}{ First part of the scoring rule } \\
\hline Section 1-Definitions & 1 & 1 & 1 & 1 & 1 & 1 \\
\hline Section 2-Calculations and limitations & 1 & 1 & 1 & 1 & 1 & 1 \\
\hline Section 3-Explanations & 4 & 4 & 4 & 4 & 4 & 5 \\
\hline Section 4-Other key disclosure parameters & 3 & 3 & 3 & 3 & 3 & 3 \\
\hline Total score of the first part & 9 & 9 & 9 & 9 & 9 & 10 \\
\hline \multicolumn{7}{|l|}{ Second part of the scoring rule } \\
\hline Section A-Key aspects of credit risk management in banking & 10 & 11 & 11 & 11 & 11.5 & 12.5 \\
\hline Section $\mathrm{B}-$ Credit risk management decision disclosure & 8.5 & 9.5 & 10 & 10 & 10.5 & 10.5 \\
\hline Section $\mathrm{C}-$ Credit risk components & 6.5 & 6.5 & 6.5 & 6.5 & 7 & 8 \\
\hline Section D-Information on credit risk exposures & 8 & 8 & 8 & 8 & 8 & 9 \\
\hline Section E-Loan losses and measurement models & 6.5 & 6.5 & 7 & 7 & 7.5 & 8 \\
\hline Section $\mathrm{F}$-Credit risk mitigation/transfer instruments & 8 & 8.5 & 9.5 & 9.5 & 9.5 & 9.5 \\
\hline Section $\mathrm{G}$-Other key elements of bank credit risk & 6 & 6.5 & 7 & 7.5 & 7.5 & 9 \\
\hline Section $\mathrm{H}-$ Bank loan portfolio disclosure & 7 & 7 & 7.5 & 7.5 & 8 & 8.5 \\
\hline Section $\mathrm{I}-$ Credit rating disclosure issues & 12.5 & 13.5 & 14.5 & 14.5 & 15 & 15.5 \\
\hline Section L-Bank credit risk capital requirements disclosure & 7.5 & 8.5 & 10 & 10 & 10 & 10.5 \\
\hline Section $\mathrm{M}-$ General credit risk disclosure issues & 5 & 5 & 5 & 5.5 & 6 & 7 \\
\hline Total score of the second part & 85.5 & 90.5 & 96 & 97 & 100.5 & 108 \\
\hline Final total score & 94.5 & 99.5 & 105 & 106 & 109.5 & 118 \\
\hline Normalized final total score & 35.25 & 36.77 & 38.39 & 38.78 & 39.97 & 43.49 \\
\hline
\end{tabular}

Table 16 Mediobanca: results of the credit risk disclosure analysis. Sources: Mediobanca, Bilancio, 2012, 2013, 2014, 2015, 2016, 2017 (it includes the Notes to the account, and the Management Commen- tary); Mediobanca, Terzo Pilastro di Basilea 2. Informativa al pubblico, 2012, 2013, 2014, 2015, 2016, 2017 (it includes the Pillar III Disclosures)

\begin{tabular}{|c|c|c|c|c|c|c|}
\hline Mediobanca 2012 & Score & 2013 & 2014 & 2015 & 2016 & 2017 \\
\hline \multicolumn{7}{|l|}{ First part of the scoring rule } \\
\hline Section 1 -Definitions & 1 & 1 & 1 & 1 & 0 & 5 \\
\hline Section $2-$ Calculations and limitations & 1 & 1 & 1 & 1 & 1 & 1 \\
\hline Section 3-Explanations & 3 & 3 & 3 & 3 & 3 & 3 \\
\hline Section 4-Other key disclosure parameters & 4 & 4 & 4 & 4 & 6 & 6 \\
\hline Total score of the first part & 9 & 9 & 9 & 9 & 10 & 15 \\
\hline \multicolumn{7}{|l|}{ Second part of the scoring rule } \\
\hline Section A-Key aspects of credit risk management in banking & 7 & 7.5 & 8 & 8.5 & 9 & 10 \\
\hline Section B-Credit risk management decision disclosure & 7.5 & 7.5 & 7.5 & 8.5 & 8.5 & 9 \\
\hline Section $\mathrm{C}-$ Credit risk components & 4.5 & 4.5 & 4.5 & 5.5 & 6.5 & 7 \\
\hline Section D-Information on credit risk exposures & 7.5 & 7.5 & 7.5 & 8.5 & 9.5 & 9.5 \\
\hline Section E-Loan losses and measurement models & 6.5 & 6.5 & 7 & 7 & 7.5 & 8 \\
\hline Section $\mathrm{F}-$ Credit risk mitigation/transfer instruments & 9.5 & 10 & 10 & 10.5 & 10.5 & 11 \\
\hline Section G-Other key elements of bank credit risk & 5.5 & 5.5 & 6 & 6.5 & 7.5 & 8 \\
\hline Section $\mathrm{H}-$ Bank loan portfolio disclosure & 8 & 8 & 8 & 8 & 8 & 8 \\
\hline Section $\mathrm{I}-$ Credit rating disclosure issues & 13 & 13 & 13.5 & 14 & 15 & 16.5 \\
\hline Section L-Bank credit risk capital requirements disclosure & 6.5 & 6.5 & 7.5 & 8 & 8 & 8.5 \\
\hline Section $\mathrm{M}-$ General credit risk disclosure issues & 5.5 & 5.5 & 5.5 & 5.5 & 6 & 6.5 \\
\hline Total score of the second part & 81 & 82 & 85 & 90.5 & 96 & 102 \\
\hline Final total score & 90 & 91 & 94 & 99.5 & 106 & 117 \\
\hline Normalized final total score & 33.46 & 33.76 & 34.67 & 36.46 & 39.20 & 45.84 \\
\hline
\end{tabular}


Table 17 BPER Banca: results of the credit risk disclosure analysis. Sources: BPER Banca, Bilancio dell'esercizio, 2012, 2013, 2014, 2015, 2016, 2017 (it includes the Notes to the account, and the
Management Commentary); BPER Banca, Informativa al pubblico. Basilea 2 Pillar 3, 2012, 2013, 2014, 2015, 2016, 2017 (it includes the Pillar III Disclosures)

\begin{tabular}{|c|c|c|c|c|c|c|}
\hline BPER Banca 2012 & Score & 2013 & 2014 & 2015 & 2016 & 2017 \\
\hline \multicolumn{7}{|l|}{ First part of the scoring rule } \\
\hline Section 1-Definitions & 1 & 1 & 1 & 1 & 1 & 1 \\
\hline Section 2-Calculations and limitations & 1 & 1 & 1 & 1 & 1 & 1 \\
\hline Section 3-Explanations & 4 & 4 & 4 & 4 & 4 & 4 \\
\hline Section 4-Other key disclosure parameters & 4 & 4 & 5 & 5 & 5 & 5 \\
\hline Total score of the first part & 10 & 10 & 11 & 11 & 11 & 11 \\
\hline \multicolumn{7}{|l|}{ Second part of the scoring rule } \\
\hline Section A-Key aspects of credit risk management in banking & 11 & 11.5 & 12.5 & 13 & 14 & 14.5 \\
\hline Section B-Credit risk management decision disclosure & 11 & 11.5 & 12.5 & 12.5 & 13 & 14 \\
\hline Section $\mathrm{C}-$ Credit risk components & 6.5 & 6.5 & 7 & 7.5 & 9 & 9 \\
\hline Section D-Information on credit risk exposures & 9 & 9 & 10.5 & 10.5 & 10.5 & 10.5 \\
\hline Section E—Loan losses and measurement models & 6.5 & 6.5 & 7 & 7 & 7.5 & 7.5 \\
\hline Section $\mathrm{F}-$ Credit risk mitigation/transfer instruments & 10 & 10.5 & 11 & 11 & 11 & 11.5 \\
\hline Section G-Other key elements of bank credit risk & 7 & 8.5 & 9 & 9 & 12 & 12 \\
\hline Section $\mathrm{H}-$ Bank loan portfolio disclosure & 7 & 7 & 7 & 7.5 & 8 & 8 \\
\hline Section $\mathrm{I}-$ Credit rating disclosure issues & 16.5 & 17 & 17 & 18.5 & 20.5 & 21 \\
\hline Section L-Bank credit risk capital requirements disclosure & 7.5 & 7.5 & 8 & 8.5 & 9.5 & 9.5 \\
\hline Section $\mathrm{M}-$ General credit risk disclosure issues & 6 & 6 & 6 & 6.5 & 7 & 7 \\
\hline Total score of the second part & 98 & 101.5 & 107.5 & 111.5 & 122 & 124.5 \\
\hline Final total score & 108 & 111.5 & 118.5 & 122.5 & 133 & 135.5 \\
\hline Normalized final total score & 39.83 & 40.91 & 43.75 & 45.03 & 48.50 & 49.24 \\
\hline
\end{tabular}

Table 18 Banca Popolare di Milano: results of the credit risk disclosure analysis. Sources: Banca Popolare di Milano, Relazione e Bilancio, 2012, 2013, 2014, 2015, 2016 (it includes the Notes to the account, and the Management Commentary); Banca Popolare di Milano, Informativa al pubblico. Pillar 3, 2012, 2013, 2014, 2015, 2016 (it includes the Pillar III Disclosures)

\begin{tabular}{llllll}
\hline Banca Popolare di Milano 2012 & Score & 2013 & 2014 & 2015 & 2016 \\
\hline First part of the scoring rule & & & & & \\
Section 1-Definitions & 7 & 7 & 2 & 3 & 3 \\
Section 2-Calculations and limitations & 1 & 1 & 1 & 1 & 1 \\
Section 3-Explanations & 4 & 4 & 4 & 4 & 4 \\
Section 4-Other key disclosure parameters & 5 & 6 & 5 & 5 & 5 \\
Total score of the first part & 17 & 18 & 12 & 13 & 13 \\
Second part of the scoring rule & & & & & \\
Section A-Key aspects of credit risk management in banking & 10 & 11 & 12 & 12.5 & 13.5 \\
Section B-Credit risk management decision disclosure & 10 & 10.5 & 11 & 11 & 12 \\
Section C-Credit risk components & 7.5 & 7.5 & 9 & 9.5 & 9.5 \\
Section D-Information on credit risk exposures & 9 & 9.5 & 10 & 10 & 11 \\
Section E-Loan losses and measurement models & 8 & 9 & 10 & 10 & 11.5 \\
Section F-Credit risk mitigation/transfer instruments & 9.5 & 9.5 & 10.5 & 10.5 & 10.5 \\
Section G-Other key elements of bank credit risk & 6 & 6 & 7 & 8 & 7.5 \\
Section H-Bank loan portfolio disclosure & 7.5 & 7.5 & 7.5 & 7.5 & 7.5 \\
Section I-Credit rating disclosure issues & 13.5 & 13.5 & 14 & 15 & 16 \\
Section L-Bank credit risk capital requirements disclosure & 8.5 & 8.5 & 8.5 & 9.5 & 10 \\
Section M-General credit risk disclosure issues & 7 & 7 & 7 & 7 & 8 \\
Total score of the second part & 96.5 & 99.5 & 106.5 & 110.5 & 117 \\
Final total score & 113.5 & 117.5 & 118.5 & 123.5 & 130 \\
Normalized final total score & 46.49 & 48.34 & 44.91 & 47.14 & 49.14 \\
\hline
\end{tabular}


Table 19 Banca Popolare di Vicenza: results of the credit risk disclosure analysis. Sources: Banca Popolare di Vicenza, Relazioni e Bilancio, 2012, 2013, 2014, 2015, 2016 (it includes the Notes to the account, and the Management Commentary); Banca Popolare di Vicenza, Terzo Pilastro di Basilea 2. Informativa al pubblico, 2012, 2013, 2014, 2015, 2016 (it includes the Pillar III Disclosures)

\begin{tabular}{|c|c|c|c|c|c|}
\hline Banca Popolare di Vicenza 2012 & Score & 2013 & 2014 & 2015 & 2016 \\
\hline \multicolumn{6}{|l|}{ First part of the scoring rule } \\
\hline Section $1-$ Definitions & 3 & 4 & 4 & 4 & 4 \\
\hline Section $2-$ Calculations and limitations & 1 & 1 & 1 & 1 & 1 \\
\hline Section 3-Explanations & 5 & 5 & 5 & 5 & 5 \\
\hline Section 4-Other key disclosure parameters & 5 & 5 & 5 & 5 & 5 \\
\hline Total score of the first part & 14 & 15 & 15 & 15 & 15 \\
\hline \multicolumn{6}{|l|}{ Second part of the scoring rule } \\
\hline Section A-Key aspects of credit risk management in banking & 9 & 10 & 11 & 12 & 12.5 \\
\hline Section $\mathrm{B}-$ Credit risk management decision disclosure & 8.5 & 8.5 & 9 & 9.5 & 10.5 \\
\hline Section $\mathrm{C}-$ Credit risk components & 5.5 & 5.5 & 6.5 & 6.5 & 7 \\
\hline Section D-Information on credit risk exposures & 9 & 9 & 9 & 9 & 9 \\
\hline Section E-Loan losses and measurement models & 7.5 & 8 & 9 & 9 & 10 \\
\hline Section $\mathrm{F}-$ Credit risk mitigation/transfer instruments & 10 & 10 & 10 & 10 & 11 \\
\hline Section $\mathrm{G}$-Other key elements of bank credit risk & 7 & 7 & 8.5 & 8.5 & 9 \\
\hline Section $\mathrm{H}-$ Bank loan portfolio disclosure & 8.5 & 9 & 9 & 9 & 9 \\
\hline Section $\mathrm{I}-$ Credit rating disclosure issues & 16.5 & 17 & 18 & 18 & 18.5 \\
\hline Section $\mathrm{L}-$ Bank credit risk capital requirements disclosure & 7 & 7.5 & 8.5 & 8.5 & 9 \\
\hline Section $\mathrm{M}-$ General credit risk disclosure issues & 7.5 & 7.5 & 7.5 & 7.5 & 8 \\
\hline Total score of the second part & 96 & 99 & 106 & 107.5 & 113.5 \\
\hline Final total score & 110 & 114 & 121 & 122.5 & 128.5 \\
\hline Normalized final total score & 42.97 & 44.83 & 47.10 & 47.60 & 49.52 \\
\hline
\end{tabular}

\section{References}

1. Akerlof, G. 1970. The market for 'lemons': Quality uncertainty and the market mechanism. Quarterly Journal of Economics 84(3): 488-500.

2. Leland, E.H., and H.D. Pyle. 1977. Informational asymmetries, financial structure and financial intermediation. Journal of Finance 32(2): 371-387.

3. Fama, E.F. 1980. Agency problems and the theory of the firm. Journal of Political Economy 88(2): 288-307.

4. Fama, E.F., and M. Jensen. 1983. Separation of ownership and control. Journal of Law and Economics 26(2): 301-325.

5. Jensen, M.C., and W.H. Meckling. 1976. Theory of the firm: Managerial behavior, agency costs and ownership structure. Journal of Financial Economics 3(4): 305-360.

6. Ross, S.A. 1973. The economic theory of agency: The principal's problem. The American Economic Review 63(2): 134-139.

7. Armstrong, C.S., W.R. Guay, and J.P. Weber. 2010. The role of information and financial reporting in corporate governance and debt contracting. Journal of Accounting and Economics 50(2-3): 179-234.

8. Dobler, M. 2008. Incentives for risk reporting. A discretionary disclosure and cheap talk approach. The International Journal of Accounting 43(2): 184-206.

9. Diamond, D. 1984. Financial intermediation and delegated monitoring. Review of Economic Studies 51(3): 393-414.

10. Ross, S.A. 1977. The determination of financial structure: The incentive-signalling approach. The Bell Journal of Economics 8(1): $23-40$

11. Botosan, C.A. 1997. Disclosure level and the cost of equity capital. The Accounting Review 72(3): 323-349.

12. Botosan, C.A., and M.A. Plumlee. 2002. A re-examination of disclosure level and the expected cost of equity capital. Journal of Accounting Research 40(1): 21-40.
13. Healy, P.M., and K.G. Palepu. 2001. Information asymmetry, corporate disclosure, and the cost of capital markets: A review of the empirical disclosure literature. Journal of Accounting and Economics 31(1-3): 405-440.

14. Leuz, C., and R. Verrecchia. 2000. The economic consequences of increased disclosure. Journal of Accounting Research 38(Supplement): 91-124.

15. Acharya, V., and M. Richardson. 2009. Restoring financial stability. New York: Wiley.

16. Acharya, V., and S.G. Ryan. 2016. Banks' financial reporting and financial system stability. Journal of Accounting Research 54(2): 277-340.

17. Crockett, A. 2002. Market discipline and financial stability. Journal of Banking \& Finance 26(5): 977-987.

18. Freixas, X., and C. Laux. 2012. Disclosure, transparency, and market discipline. In The crisis aftermath: New regulatory paradigms, ed. M. Dewatripont and X. Freixas, 69-104. London: Centre for Economic Policy Research.

19. Morgan, D. 2002. Rating banks: Risk and uncertainty in an opaque industry. American Economic Review 92(4): 874-888.

20. Nier, E., and U. Baumann. 2006. Market discipline, disclosure and moral hazard in banking. Journal of Financial Intermediation 15(3): 332-361.

21. Fama, E.F. 1970. Efficient capital markets: A review of theory and empirical work. Journal of Finance 25(2): 383-417.

22. Financial Stability Board. 2011. Thematic review on risk disclosure practices (Peer review report). Basel.

23. Financial Stability Board. 2012. Enhancing the risk disclosures of banks. Basel.

24. Foster, G. 1980. Externalities and financial reporting. Journal of Finance 35(2): 521-533.

25. Basel Committee on Banking Supervision. 2000. Best practices for credit risk disclosure. Basel. 
26. Basel Committee on Banking Supervision. 2006. International convergence of capital measurement and capital standards: A revised framework. Basel.

27. Basel Committee on Banking Supervision. 2011. Basel 3: A global regulatory framework for more resilient banks and banking systems. Basel.

28. Krippendorff, K. 2004. Content analysis: An introduction to its methodology. Thousand Oaks, CA: Sage.

29. Berelson, B. 1952. Content analysis in communication research. Illinois: Free Press.

30. Holsti, O.R. 1969. Content analysis for the social sciences and humanities. Reading, MA: Addison-Wesley Publishing Company.

31. Weber, R.P. 1990. Basic content analysis. Beverly Hills, CA: Sage.

32. Abraham, S., and P. Cox. 2007. Analysing the determinants of narrative risk information in UK FTSE 100 annual reports. The British Accounting Review 39(3): 227-248.

33. Beattie, V.A., B. McInnes, and S. Fearnley. 2004. A methodology for analyzing and evaluating narratives in annual reports: A comprehensive description profile and metrics for disclosure quality attributes. Accounting Forum 28(3): 205-236.

34. Bryan, S.H. 1997. Incremental information content of required disclosures contained in management discussion and analysis. The Accounting Review 72(2): 285-301.

35. Kissing, P. 2016. Corporate disclosures and financial risk assessment. Wien: Springer.

36. Linsley, P., and P. Shrives. 2000. Risk management and reporting risk in the UK. Journal of Risk 3(1): 115-129.

37. Linsley, P.M., and P.J. Shrives. 2006. Risk reporting: A study of risk disclosures in the annual reports of UK companies. The British Accounting Review 38(4): 387-404.

38. Neri, L. 2011. Risk reporting: Development, regulation and current practice. Milan: Franco Angeli.

39. Verrecchia, R.E. 2001. Essays on disclosure. Journal of Accounting and Economics 32(1-3): 97-180.

40. Ahmed, A.S., E. Kilic, and G.J. Lobo. 2006. Does recognition versus disclosure matter? Evidence from value-relevance of bank's recognized and disclosed derivate financial instruments. The Accounting Review 81(3): 567-588.

41. Fortuna, F. 2002. I derivati su crediti nell'economia e nel bilancio delle banche. Milan: Franco Angeli.

42. Jorion, P. 2002. How informative are value-at-risk disclosures? The Accounting Review 77(4): 911-931.

43. Woods, M., K. Dowd, and C. Humphrey. 2008. Market risk reporting by the world's top banks: Evidence on the diversity of reporting practice and the implications for international accounting harmonization. Spanish Accounting Review 11(2): 9-42.

44. Woods, M., K. Dowd, and C. Humphrey. 2008. The value of risk reporting: A critical analysis of value-at-risk disclosures in the banking sector. International Journal of Financial Services Management 3(1): 45-64.

45. Ryan, S. 2012. Risk reporting quality: Implications of academic research for financial reporting policy. Accounting and Business Research 42(3): 295-324.

46. Gray, S.J., L.B. McSweeney, and J.C. Shaw. 1984. Information disclosure and the multinational corporation. New York: Wiley.

47. Tonkin, D.J. 1989. World survey of published accounts: An analysis of 200 annual reports from the world's leading companies. London: Lafferty Publications.

48. Cooke, T.E. 1989. Disclosure in the corporate annual reports of Swedish companies. Accounting and Business Research 19(74): 113-124.

49. Chow, C.W., and A. Wong-Boren. 1987. Voluntary financial disclosure by Mexican corporations. Accounting Review 62(3): 533-541.
50. Marston, C.L., and P.J. Shrives. 1991. The use of disclosure indices in accounting research: A review article. The British Accounting Review 23(3): 195-210.

51. Core, J. 2001. A review of the empirical disclosure literature: Discussion. Journal of Accounting and Economics 31(1-3): 441-456.

52. Elshandidy, T., P.J. Shrives, M. Bamber, and S. Abraham. 2018. Risk reporting: A review of literature and implications for future research. Journal of Accounting Literature 40(1): 54-82.

53. Beattie, V.A., and S. Liao. 2014. Financial accounting in the banking industry: A review of the empirical literature. Journal of Accounting and Economics 58(2): 339-383.

54. Beretta, S., and S. Bozzolan. 2004. A framework for the analysis of firm risk communication. The International Journal of Accounting 39(3): 265-288.

55. Beretta, S., and S. Bozzolan. 2008. Quality versus quantity: The case of forward-looking disclosure. Journal of Accounting, Auditing and Finance 23(3): 333-375.

56. Bozzolan, S., M. Trombetta, and S. Beretta. 2009. Forward-looking disclosures, financial verifiability and analysts' forecasts: A study of cross-listed European firms. European Accounting Review 18(3): 435-473.

57. Linsley, P., and P. Shrives. 2005. Transparency and the disclosure of risk information in the banking sector. Journal of Financial Regulation and Compliance 13(3): 205-214.

58. Linsley, P.M., P.J. Shrives, and M. Crumpton. 2006. Risk disclosure: An exploratory study of UK and Canadian banks. Journal of Banking Regulation 7(3-4): 268-282.

59. Barth, M.E., and W.R. Landsman. 2010. How did financial reporting contribute to the financial crisis? European Accounting Review 19(3): 399-423.

60. Fortuna, F. 2010. L'informativa su rischi delle banche. Milan: Franco Angeli.

61. Gaetano, A. 1996. Il sistema dei rischi nel bilancio di esercizio degli enti creditizi. Padova: Cedam.

62. Helbok, G., and C. Wagner. 2006. Determinants of operational risk reporting in the banking industry. Journal of Risk 9(1): 49-74.

63. Malinconico, A. 2007. La disclosure dei rischi nelle banche: Possibili effetti sulla disciplina di mercato. Banche e Banchieri 5: 369-383.

64. Maffei, M. 2017. La disclosure sui rischi con particolare riferimento alle banche. Turin: Giappichelli.

65. Scannella, E. 2018. Market risk disclosure in banks' balance sheet and pillar 3 report: The case of Italian banks. In Contemporary issues in banking: Regulation, governance and performance, ed. M. García-Olalla and J. Clifton, 53-90. London: Palgrave Macmillan.

66. Scannella, E., and S. Polizzi. 2018. Market risk disclosure in banking: An empirical analysis on four global systemically important European banks. Journal of Banking Regulation 19(2): 87-100.

67. Tutino, F. 2013. Analisi dei rischi finanziari delle banche: E' necessario utilizzare gli strumenti dell'economia aziendale? Bancaria 69(10): 28-42.

68. Tutino, F., G. Birindelli, and P. Ferretti. 2011. Basilea 3: Gli impatti sulle banche. Milan: Egea.

69. Rutigliano, M. 2011. Il bilancio della banca. Milan: Egea.

70. Rutigliano, M. 2016. Il bilancio delle banche e degli altri intermediari finanziari. Milan: Egea.

71. Rutigliano, M. 2012. L'analisi del bilancio delle banche. Milan: Egea.

72. Frolov, M. 2006. Bank credit risk disclosure in Japan. Journal of Banking Regulation 7(3-4): 221-242.

73. Bessis, J. 2015. Risk management in banking. New York: Wiley.

74. Hull, J. 2018. Risk management and financial institutions. New York: Wiley. 
75. Mottura, P. 2011. Banche: Strategie, organizzazione e concentrazioni. Milan: Egea.

76. Mottura, P. 2016. Banca: Economia e gestione. Milan: Egea.

77. Sironi, A., and A. Resti. 2008. Rischio e valore nelle banche. Milan: Egea.

78. International Accounting Standard Boards. 2010. The conceptual framework for financial reporting, London.

79. Lev, B. 1992. Information disclosure strategy. California Management Review 34(4): 9-32.

80. Begley, T.A., A. Purnanandam, and K. Zheng. 2017. The strategic under-reporting of bank risk. The Review of Financial Studies 30(10): 3376-3415.

81. Basel Committee on Banking Supervision. 2015. Revised pillar 3 disclosure requirements. Basel.

82. Basel Committee on Banking Supervision. 2017. Pillar 3 disclosure requirements: Consolidated and enhanced framework. Basel.

83. Bisoni, C., S. Olivetti, B. Rossignoli, and P. Vezzani. 2012. Il bilancio della banca e l'analisi della performance. Rome: Bancaria Editrice.

84. Dell'Atti, A. 2009. I principi contabili internazionali nell'economia e nei bilanci delle banche. Bari: Cacucci Editore.

85. Barabàsi, A.L. 2002. Linked: The new science of networks. Cambridge, MA: Perseus.

86. Narum, S.R. 2006. Beyond Bonferroni: Less conservative analyses for conservation genetics. Conservation Genetics 7(5): 783-787.

87. Kruskal, J.B. 1956. On the shortest spanning subtree of a graph and the traveling salesman problem. Proceedings of the American Mathematical Society 7(1): 48-50.

88. Polizzi, S., and E. Scannella. 2020. An empirical investigation into market risk disclosure: Is there room to improve for Italian banks? Journal of Financial Regulation and Compliance 28(3): 465-483.

89. Barakat, A., and K. Hussainey. 2013. Bank governance, regulation, supervision, and risk reporting: Evidence from operational risk disclosures in European banks. International Review of Financial Analysis 30: 254-273.

90. Barnouw, et al. 2018. International encyclopedia of communications. Oxford: Oxford University Press.

Publisher's Note Springer Nature remains neutral with regard to jurisdictional claims in published maps and institutional affiliations.

Enzo Scannella is a MBA, Ph.D., Full Professor of Banking and Finance, Department of Economics, Business, and Statistics, University of Palermo. He has been a Visiting Scholar at Harvard Business School, Boston, USA; Visiting Professor at Universidad Autonoma de Madrid, and Regent's University London. His research interests are: bank management, bank regulation, risk management, financial innovation. He is a member of various university research groups, editorial boards, and scientific committees for conferences. He is a member of the European Association of University Teachers in Banking and Finance (Wolpertinger), the Italian Academy of Management (AIDEA), the Italian Association of University Teachers in Banking and Finance (ADEIMF).

Salvatore Polizzi is a Ph.D. candidate in Economics and Statistics at the Department of Economics, Business and Statistics, University of Palermo, Italy. He has a Master's Degree in Economics and Finance cum laude at the University of Palermo. He held a visiting researcher position at the Bangor Business School, Bangor University, UK. He is doing research on bank accounting and risk management at the University of Palermo. He is a member of the European Association of University Teachers in Banking and Finance (Wolpertinger) and of the Italian Association of University Teachers in Banking and Finance (ADEIMF). 